\title{
Post Earnings Announcement Drift, liquidity and Zero Leverage Firms: Evidence from the UK Stock Market.
}

\author{
Sijia Zhang and Andros Gregoriou* \\ All authors are from Brighton Business School, University of Brighton, Mithras House, \\ Lewes Road, Brighton. BA2 4NT, UK.
}

\begin{abstract}
We investigate the empirical relationship between liquidity costs and Post Earnings Announcement Drift, using a sample of 93 zero-leverage firms listed on the FTSE 350 index over the time period 2000-2015. We discover that illiquidity levels are significantly enhanced around both the earnings and post announcement period, in both the short and long run. Once we decompose the bid-ask spread components during the earnings announcements, we observe that the adverse selection costs are significantly increased, whereas the inventory holding and order processing costs remain unchanged. We conclude that Post Earnings Announcement Drift is related with information asymmetry for zero-leverage firms.
\end{abstract}

JEL code: G10, G14

Keywords: Post Earnings Announcement Drift; Zero-leverage firms; Liquidity; Amihud Ratio; Spread Decomposition.

* Denotes Corresponding Author. 


\section{Introduction}

One of the most common anomalies in financial markets is the stock price reaction to corporate earnings announcements. Over the past several decades researchers have been puzzled by the manner in which a company's stock price responds after earnings announcements. When firms publicize the information contained in earnings surprises, prices continue to move in the same direction for several weeks or even months. This phenomenon is called post earnings announcement drift (PEAD) and goes against the efficient market hypothesis, which indicates that all public information should be reflected in stock prices. Since Ball and Brown (1968) discovered PEAD for the US market, the PEAD anomaly has been examined worldwide with mixed evidence. For instance, the PEAD exists in countries such as UK (Hew et al., 1996), Spain (Forner and Sanabria, 2010) and New Zealand (Truong, 2010). On the other hand, other countries find little evidence of PEAD such as Belgium (Van Huffel et al., 1996) and Singapore (Ariff et al., 1997).

The most widely accepted explanation concerning the cause of PEAD is the mispricing of earnings announcement information (Bernard and Thomas, 1989). More information is competing for investors' attention than they can process. This implies that investors are inattentive and under-react to earnings announcements. This under-reaction does not adjust as quickly as it should (Hirshleifer et al. 2009). On the other hand, Alwathnani et al. (2017) document that drift arises when investors overweight extreme and surprising events, especially during the 3-day short-term event window. Drift can arise when some investors overreact to their private information and underweight public earnings reports. These investors coupled with their self-attribution biases, may tend to be overconfident about the information that they have generated relative to public signals. 
A second possible cause of PEAD is associated with stock market inefficiency. This is because prices delay in response to new information as the market does not anticipate the full contents of the news. The delay in prices could be explained by traders not using all available information or due to transaction costs (Hirshleifer et al., 2009). Another possible cause of PEAD, is that the Capital Asset Pricing model (CAPM) used to establish stock market reaction to news is incorrect, leading to PEAD (Ball, 1992).

In this paper, we aim to examine the PEAD anomaly of zero-leverage firms and the liquidity cost effects on the drift. A zero-leverage firm is defined as a company that has zero outstanding debt. The zero-leverage policy is becoming increasingly popular over time. Devos et al. (2012) show that in the US market, the public firms that follow zero-leverage policy increases constantly, from $8.4 \%$ in 1990 to $18.6 \%$ in 2008. Dang (2013) provides evidence in the UK market from 1980 to 2007 , that more than $12.8 \%$ of UK firms have no debt in their capital structure. Zhang and Gregoriou (2019) report that in the London Stock Exchange, zeroleverage firms have relatively wider percentage bid-ask spreads, higher transaction costs, more information asymmetry and volatility of returns. Faulkender and Petersen (2006) discover that zero-leverage firms are more informationally opaque, very little public information is available about such firms, the analysts pay less attention to them, and given their small size the relative collecting information cost can be quite high (Slovin et al., 1992). Therefore, the information obtained from earnings announcements becomes important for the market. On the other hand, Slovin et al. (1992) demonstrate that small firms which are younger and have less public information face more severe adverse selection problems. Thus, they exhibit greater impact from the earnings announcement. Given the interesting characteristics of zero-leverage firms, we believe that, the PEAD of zero-leverage firms is important to examine. In our study, we attempt to answer the following research questions: First, does the PEAD anomaly exist around 
the zero-leverage firms earnings announcement period? Second, if the PEAD anomaly for zero leverage firms around the earnings announcement does exist, is it related with liquidity levels and information asymmetry costs?

Our empirical results reveal that there is strong evidence of PEAD for zero-leverage firms in the post-earnings period. This is accompanied by significant decreases in liquidity. The bidask spreads are larger, and both price impact (illiquidity) ratios, are enhanced in the post earnings announcement period. Second, when we decompose the bid-ask spread into its three components, we observe that the adverse selection costs are significantly increased, whereas the inventory holding and order processing costs are unchanged. Therefore, we conclude that the PEAD anomaly is related with information asymmetry for zero-leverage firms. Third, in our regression analysis we show that the relation between earnings surprises, liquidity costs and PEAD returns is robust, when we control for several firm characteristics such as firm size, stock price and trading volume. We report that greater PEAD is related with higher liquidity costs. Furthermore, for robustness we re-examine our analysis using different short-and longrun event windows and alternative definitions of zero-leverage firms. Our results are robust to alternative event windows and definitions of zero-leverage firms.

Our study contributes to the previous research in the following ways. First, we are the only study to provide a comprehensive analysis of liquidity costs and the PEAD anomaly on the UK stock market. Prior research on PEAD in the UK by Hew et al. (1996), and Liu et al. (2003) do not attempt to explain the anomaly by liquidity costs. Most papers which link the liquidity and PEAD anomaly are focused on the U.S. market (e.g. Chordia et al., 2009; Ng et al., 2008). The second contribution to the literature is that we are the first research paper to empirically examine the PEAD anomaly for zero-leverage firms. The PEAD anomaly has been found to 
be stronger in smaller, lower-priced, less liquid, and more volatile securities that are followed by less sophisticated investors (Bernard and Thomas, 1989; Bhushan, 1994 and Bartov et al., 2000). Chordia et al. (2009) show that PEAD mainly occurs in stocks with high trading costs, which usually exhibit high levels of illiquidity. Given that zero-leverage firms suffer from greater information asymmetry (Zhang and Gregoriou, 2019) and are considered illiquid, we would expect greater PEAD than for companies that possess a capital structure of debt and equity.

Third, our research examines the liquidity effect on PEAD in both the short and long run. Previous research by $\mathrm{Ng}$ et al. (2008) examine the trading costs associated with PEAD using the entire bid-ask spread to reflect the information environment of companies. The bid-ask spread is a very good measure of the short-term impact of news on equity prices, because it captures market maker's reaction to information. However, you cannot acquire the long-term effect of PEAD with the bid-ask spread, because market maker's compensation will go back to equilibrium in the long-term. In order to examine the long run effects of liquidity on PEAD we use the Amihud (2002) illiquidity ratio (stocks daily return divided by its daily monetary volume, RtoV), and an alternative measure of illiquidity developed by Florackis et al. (2011), RtoTR (the average ratio of daily absolute stock return divided by its turnover ratio). These two ratios encapsulate the long-term liquidity of a company as permanent changes in prices reflect alterations in the information environment of a firm. ${ }^{1}$

Finally, we examine the liquidity costs by decomposing the bid-ask spread into three components namely adverse selection, inventory holding and order processing costs. Several studies have provided evidence of a relationship between transaction costs and PEAD. For

\footnotetext{
${ }^{1}$ Like previous studies we use the bid-ask spread as our short run liquidity proxy.
} 
example, Bhushan (1994) and Ng et al. (2008) show that the magnitude of PEAD is related to trading costs. Both studies make the unrealistic assumption that changes in total bid-ask spreads are directly associated with movements in the information environment of a security. Through examining changes in every individual element of the bid-ask spread we are able to establish if PEAD can be explained by variations in information and/or trading costs.

The rest of this study is organized as follows. Section 2 provides a review of the previous literature and our three testable hypotheses. Section 3 presents the data. Section 4 describes the methodology used to undertake the research, including PEAD measurement, spread decomposition, illiquidity methods, event studies and multivariate tests. The empirical analysis is reported in Section 5 and finally in Section 6 we conclude.

\section{Literature Review}

\subsection{PEAD}

Ball and Brown (1968) analyse earnings data for US companies from 1946-1966, and discover that stock prices respond positively to unexpectedly higher earnings than the expected earnings in the next period. The magnitude of unexpected earnings changes and its relationship with stock prices provide a different way of measuring the earnings information. The evidence of PEAD was later supported by Jones and Litzenberger (1970) in their investigation of quarterly earnings with a sample of stocks on the US market between 1962 and 1967. They establish that markets do not adjust instantaneously and correctly when new information arrives, causing PEAD. Foster et al. (1984) show that high PEAD returns are compensation for bearing risks of firms with extreme earnings surprises. It is a persistent phenomenon in their sample period from 1974 to 1981 in the US market. Bernard and Thomas (1989) examine stocks in the US market over the period 1974-86 and find that a large amount of the drift takes place in the first 60 days following the announcement day. During the first 60 day period, the drift is $13 \%$ for 
small firms, $18 \%$ for medium firms, and 20\% for large firms. Both Foster et al. (1984) and Bernard and Thomas (1989) document that the magnitude of the PEAD is negatively associated with firm size. Livnat and Mendenhall (2006) obtain 5.21\% PEAD return per quarter using a sample of US stocks from 1987-2003. Cao and Narayanamoorthy (2012) demonstrate that for their US sample, the persistence of earnings surprises is equally important along with market reactions to the magnitude of the earnings surprise. The PEAD returns due to earnings volatility is a general phenomenon, they are not concentrated in firms with the largest trading frictions. Bartov et al. (2000) suggest that firms with less institutional following have stronger PEAD, since institutional investors are sophisticated market participants less likely to underreact to earnings information. Eom et al. (2019) focus on the individual investors in the Korean market, find that individual market participants tend to trade in the opposite direction to earnings surprises. This impedes a full price response to earnings news, leading to under-reaction and PEAD.

Van Huffel et al. (1996) suggest that the standard deviation of the unexpected earnings is much higher for small firms, since small firms have a more volatile earnings process. Doyle et al. (2006) support Van Huffel et al. (1996) by providing the evidence that at the time of the announcement, firms with extreme earnings surprises are generally smaller than the average firms. Firms with large positive earnings surprises experience large positive stock returns over the three years subsequent to the earnings announcement in the US market. Truong (2011) also reports that firms with large positive earnings surprises exhibit significant positive abnormal returns. However, the effect lasts for only one year following the earnings announcement in the Chinese market. 
There are several UK studies which focus on the PEAD anomaly. Hew et al. (1996) provide evidence to support PEAD in the UK market, and that PEAD is more evident for smaller firms. Liu et al. (2003) measure earnings surprises based on earnings, returns and analyst forecasts respectively. They confirm the existence of PEAD in the UK regardless of the measure of earnings surprise that is used. In our study, we use the earnings announcement based measurement given that it is more suitable for our sample group. More recently, Dargenidou et al. (2018) base on 7980 annual earnings announcements in the UK between 1995 to 2013, reports that the return difference between the top and bottom unexpected earnings quintiles is as large as 3.4\%. This PEAD persists for a duration of up to six months. Their UK study focus on the implications of corporate insider trading for the PEAD anomaly rather than the liquidity aspect of drift. Therefore, we test the following hypothesis:

H1: The PEAD anomaly exists for UK zero-leverage firms. The post announcement returns are positive for firms with positive earnings surprise, negative for firms with negative earnings surprise.

\subsection{PEAD and liquidity}

Prior research on PEAD assesses the ability of liquidity risk, such as transaction costs, to explain the drift (e.g.: Bhushan, 1994; Sadka, 2006; Ng et al., 2008 and Zhang et al., 2013). Bhushan (1994) argues that a significant proportion of drift is due to transactions costs. The author separates the trading cost into direct costs which include the bid-ask spreads and commissions, and indirect trading costs which consist of price pressure of large trade quantities and delay in executing an entire order. The magnitude of PEAD is positively associated with both the direct and indirect costs of trading, and is negatively related to trading volume and stock price. $\mathrm{Ng}$ et al. (2008) find that transaction costs can provide an explanation for both the 
persistence and the existence of PEAD, higher transaction costs are linked with higher subsequent returns drift. Furthermore, they find that there is no significant evidence between stock price and PEAD. Chordia et al. (2009) analyze more than 1800 U.S. stocks from 1972 to 2005, find that the PEAD occurs mainly in highly illiquidity stocks which usually have higher trading costs. Thus, we test our second hypothesis:

$\mathrm{H} 2$ : PEAD anomaly is greater for zero-leverage firms which are smaller and more illiquid than levered firms.

On the other hand, Kaniel et al. (2012) use NYSE data report that liquidity provision explains roughly only half of the abnormal return associated with trading before the earnings announcement, with the rest attributable to private information. The information component is stronger for smaller firms. Zhang et al. (2013) use a sample based on 4445 US stocks for the period 1993 to 2007. They propose two hypotheses, information content which indicates that public information has a stronger relationship with the firms with higher information risk. This implies that traders react more strongly to the earnings surprises of firms with higher information risk. Their second hypothesis is associated with transaction costs, which suggests that transaction costs are positively associated with PEAD returns. Their comprehensive study discovers that lower information quality leads to higher transaction costs, which in turn delays the flow of information into stock prices. However, they do not examine how the different spread components impact the PEAD return.

Sadka (2006) observes that a substantial part of PEAD returns can be viewed as compensation for liquidity risk. Using NYSE-listed stocks, he decomposes stock liquidity into two dimensions: Permanent versus transitory effects of trading on stock prices, and fixed costs 
versus variable costs per share traded. He reveals that only the variable-permanent component, which is associated with private information, can explains a portion of PEAD returns, since the variable-permanent price effect depends on the quantity and quality of private information. Vega (2006) argues that PEAD is associated with the arrival rate of informed or uninformed traders in the US market, and whether the information is public or private is irrelevant.

Imhoff and Lobo (1992) find the stock price response to the unexpected earnings surprises is based on the degree of information uncertainty from 1979-1984 in the US market. This is because it is more sensitive for firms with a more transparent information environment. Francis et al. (2007) find that for the US stock market between 1982-2001, most of the PEAD returns are concentrated in stocks with high information uncertainty, and greater PEAD returns for higher idiosyncratic volatility stocks can be explained by the greater information uncertainty. Brown et al. (2009) investigate the earnings surprises and information asymmetry level in US markets. They find that information asymmetry decreases after positive earnings surprises, whereas it increases after negative earnings surprises. The relationship is stronger when the earnings surprises are more likely to capture investors' attention. Chung and Hrazdil (2011) reveal that firms with superior informational environments experience significantly lower PEAD returns. Park et al. (2014) discover that the magnitude of information asymmetry differs with the different direction of earnings surprises (positive or negative), for Korean data from 2001-2010. Son et al. (2018) conclude that the market participants can facilitate a more efficient processing of earnings if the information from the past is available. This leads to a smaller degree of PEAD. Thus, we test the following related hypothesis:

H3: PEAD anomaly of zero-leverage firms are related with the information asymmetry. 


\section{Data}

Zero-leverage firms in our study are defined as companies with no short or long-run debt during our sample period. Our data sample consists of all zero-leverage firms listed on the FTSE 350 index, from January 2000 to the end of December $2015^{2}$. The FTSE 350 is a market capitalization weighted stock market index which consists of the largest 350 firms listed on the London Stock Exchange. It combines the FTSE 100 and FTSE 250 index, representing approximately $89 \%$ of the entire trading volume on the London Stock Exchange. This enables us to obtain an accurate description of the UK stock market. ${ }^{3}$ We also acquire the corresponding data for all FTSE 350 firms for comparison purposes. In total, there are 93 zeroleverage firms within the FTSE 350 that have sufficient data for our study. There are 5730 quarterly earnings announcements after restricting the announcements to those with sufficient data to conduct our empirical investigations. In order to compare how the leverage level of the sample firms influence PEAD, we acquire a sub-sample of zero-leverage firms that lever up for the first time. This is done by them securing an initial bank loan. We compare the PEAD between the pre and post-lever up period in the same sample firms ${ }^{4}$. There are 44 zero-leverage firms that lever up during our sample period.

We collect quarterly earnings announcement dates and earnings reports from Thomas Reuter Eikon, a worldscope fundamental financial database. Previous studies have focused on the firm size and drift (Foster et al., 1984; Bernard and Thomas, 1989 and Bhushuan, 1994). Therefore, we obtain the zero-leverage firms' market capitalization (number of shares traded multiplied by the share price). Following Bhushan (1994), we collect share price as one of the variables since it is a proxy for the inverse of direct costs of trading. Trading volume, is used as a proxy

\footnotetext{
${ }^{2}$ Our sample excludes financial, utility companies and closed-end funds.

${ }^{3}$ For more information viewers are referred to the FTSE 350 factsheet http://www.ftse.com/Analytics/Factsheets/temp/1550722b-648a-4ee7-82d6-bed50f09bb55.pdf.

${ }^{4}$ In our dataset the announcement and the issue date of the loan are identical.
} 
of indirect transaction costs. Bhushan (1994) believe that the drift is inversely related to both the share price and trading volume. We also collect the turnover ratio (the average number of shares outstanding during the period divided by the total number of shares traded) for one of our price impact (illiquidity) ratio measurements. Furthermore, we collect bid and ask prices in order to compute the effective spread.

\section{Methodology}

\subsection{Measurement of earnings surprises}

The prior PEAD literature measures earnings surprises using two methods. The analyst forecasts-based model (e.g. Liang, 2003; Livnat and Mendenhall, 2006; and Park et al., 2014) and the Earnings announcement model (e.g.Ng et al., 2008). As we mention above, zeroleverage firms attract less attention from analysts. Moreover, analysts' forecasts can be a noisy measure if analysts fail to reflect all available information into their forecasts (Dichev and Tang, 2009). Easterwood and Nutt (1999) point out that analysts' forecast-based measures could be a poor measure of the degree of information asymmetry. Analysts over-react to positive information and under-react to negative information. For some markets, the availability of analyst forecast data is limited to recent years (e.g. in Tallinn stock exchange, the analyst report is available from 2006, Laidroo and Grigaliuniene, 2014). Thus, we use the seasonal random-walk model $(U E)$ which refers to drift as the standardized unexpected earnings.

We define earnings surprise for zero-leverage firm $i$ at time $t, U E$, as:

$$
\mathrm{UE}_{\mathrm{i}, \mathrm{q}}=\frac{E_{i, t}-E i, q-4}{M V_{i, q-4}}
$$

Where $E_{i, t}$ is the most recent quarterly earnings, $E_{i, q-4}$ is the quarterly earnings four quarters before, and $M V_{i, q-4}$ is the market capitalization four quarters earlier. There are several papers 
that scale the changes between the most recent quarterly earnings and previous four quarters by the standard deviation of prior unexpected earnings (e.g.: Chordia et al., 2009). In our study, we follow Van Huffel et al. (1996) and $\mathrm{Ng}$ et al. (2008), by using market value to scale the changes of earnings as it provides the largest sample for us. Based on the distribution of the earnings surprises, the sample firms are assigned into decile and quintile portfolios.

\subsection{Measurement of Transaction costs: Effective spread and their decomposition}

Following $\mathrm{Ng}$ et al. (2008), we obtain effective the bid-ask spread as one of our approximations of liquidity risk. The bid-ask measure is directly observable and it reflects the real transaction costs paid by market participants. The most direct measure is the absolute bid-ask spread, which is the difference between the bid and ask price. However, some researches such as Madhavan et al. (1997) indicate that the absolute bid-ask spread is not reliable for measuring investors' trading costs. This is because many trades are executed within the bid-ask spread, resulting in absolute bid-ask spreads overstating the trade execution cost. The effective spread overcomes the weaknesses of the absolute spread. It is based on the notion that the trade is only costly to the investors to the extent that the trade price deviates from the true price. It is approximated by the bid-ask price midpoint:

$$
\text { Midpoint }=\frac{\text { Bid price }+ \text { ask price }}{2}
$$

On a round-turn, the cost would be incurred twice, hence the measure of the effective spread is calculated as twice the absolute value of the actual execution price minus the mid-point of the quoted spread immediately before the transaction. In mathematical terms this can be illustrated by equation (3).

$$
\mathrm{ES}_{\mathrm{i}, \mathrm{t}}=2\left|\mathrm{P}_{i, t}-\mathrm{Mid}_{i, t}\right|
$$


Where $E S_{i, t}$ refers to the effective bid-ask spread of stock $i$ at time period $t . P_{i, t}$ is the stock price of stock $i$ at time period $t$ and $\operatorname{Mid}_{i, t}$ is the midpoint between the bid and the ask price of stock $i$ at time period $t$.

In order to further examine the effect of information advantages that informed investors may have, we use the Huang and Stoll (1997) model for reporting the effective spread decomposition. Defining the trader indicator as $Q, Q=1$ if a transaction is buyer initiated, $Q=-$ 1 if it is seller initiated and $Q=0$ if the transaction occurs at the midpoint. Therefore, the threeway decomposition model is:

$$
\begin{gathered}
\mathrm{E}\left(\mathrm{Q}_{t-1} \mid \mathrm{Q}_{t-2}\right)=(1-2 \pi) \mathrm{Q}_{t-2} \\
\Delta \mathrm{Mid}_{t}=(\alpha+\beta) \frac{\mathrm{S}_{t-1}}{2} \mathrm{Q}_{t-1}-\alpha \frac{\mathrm{S}_{t-2}}{2} \mathrm{Q}_{t-2}(1-2 \pi)+\varepsilon_{t}
\end{gathered}
$$

Where $S$ is the spread of stock $i$ at time $t, \pi$ is the probability of a trade flow reversal. Mid $d_{t}$ is the midpoint of the bid-ask spread of stock $i$ at time $t . \alpha$ and $\beta$ are the percentages of the halfspread attributable to the adverse selection and inventory holding cost respectively. Since $\alpha$ and $\beta$ are stated as proportions, the order processing component equal to $1-(\alpha+\beta) . \frac{s_{t-1}}{2}$ is the half spread at time $t-1$. The public information component is captured by $\varepsilon_{t}$.

As we have discussed in Section 1, bid-ask spreads measure liquidity in the short run. In 2002, Amihud developed a measure of stock illiquidity that is calculated using daily or monthly price and trading volume data. The Amihud (2002) ratio measures illiquidity as the average of daily price impacts of the order flow. This allow us to examine the profitability of the long-short strategy (Chordia et al., 2009). Amihud's illiquidity, or the RtoV ratio is defined as the absolute daily return on stock $i$, divided by the firm's daily monetary volume, averaged over the trading period. 


$$
\mathrm{RtoV}_{\mathrm{i}}=\frac{1}{\mathrm{D}_{i}} \sum_{d=1}^{\mathrm{D}_{i}} \frac{\left|\mathrm{R}_{i, d}\right|}{\mathrm{V}_{i, d}}
$$

Where $\left|R_{i, d}\right|$ and $V_{i, d}$ refers to the absolute return and monetary volume of stock $i$ on day $d$ respectively, $D_{i}$ is the number of trading days for stock $i$. Amihud's ratio computes the average daily price related to a unit of trading volume. It is straightforward and easy to calculate over long-run time periods and data is readily available from financial databases. However, Florackis et al. (2011) investigate that the Amihud ratio carries a significant size bias because trading volume is positively related with firm size. Thus, the Amihud ratio is not comparable across stocks with different sizes. Given these shortcomings, Florackis et al. (2011) construct a new illiquidity ratio, defined as the average ratio of the daily absolute stock return to its turnover ratio (RtoTR ratio):

$$
\operatorname{RtoTR}_{\mathrm{i}}=\frac{1}{\mathrm{D}_{i}} \sum_{d=1}^{\mathrm{D}_{i}} \frac{\left|\mathrm{R}_{i, d}\right|}{\mathrm{TR}_{i, d}}
$$

Where $T R_{i, d}$ denotes the turnover ratio of stock $i$ at day $d, D_{i}$ and $R_{i, d}$ are the same as previously defined in equation (6). The RtoTR ratio is free of any size bias, as there is no direct correlation between firm size and turnover. Thus, it can be compared across firms with different market capitalizations (Florackis et al., 2011). In our empirical framework we compute both the RtoV and RtoTR ratios for completeness.

\subsection{Event Study}

We calculate daily abnormal returns for both short and long-run periods around the announcement date. To be precise, for every stock with sufficient data at the announcement date, we examine abnormal returns (ARs) for a three-day period around the announcement day $[-1,+1]$. Following Ng et al. (2008) and Truong (2011), to avoid the noisy information during the earnings announcement day, we compute the ARs from the first day after the earnings announcement to the 60 days after the announcement $[+1,+60]$. Bernard and Thomas (1989) 
demonstrate that the abnormal returns are predictable up to 60 trading days after quarterly earnings announcements. Therefore, we choose the long-term event window from 1 day after the earnings announcement until 60 days after the earnings announcement. More specifically, we estimate the abnormal returns by using the following econometric market-adjusted model:

$$
\mathrm{AR}_{i, t}=\mathrm{R}_{i, t}-\mathrm{R}_{m, t}
$$

Where $A R_{i, t}$ is the abnormal return earned by stock $i$ at time $t . R_{i, t}$ is the return on stock $i$ at time $t$, and $R_{m, t}$ is the value-weighted market index return at time $t$. As a proxy for the market's return, we obtain the FTSE index returns for the event period. Cumulative abnormal return (CAR) of the event window surrounding the announcement date can be calculated using the following model:

$$
\mathrm{CAR}_{\mathrm{i}, t(-q,+q)}=\sum_{t=q}^{\mathrm{S}} \mathrm{AR}_{i, t}
$$

Where $q$ represents the different time periods during the event window. The standard $t$-test is used to test if the $A R_{i, t}$ and $C A R_{i, t}$ differ significantly from zero. There are also other return models that are widely used in the financial literature. For example the CAPM by Brown and Warner (1980). However, according to Fama (1998), the CAPM model can produce spurious abnormal returns when an event sample is tilted towards small stocks such as zero-leverage firms. Another classical return measurement, buy-and-hold returns (hereafter BHARs), also has been widely used in recent literature for examining the long-term returns (e.g. Doyle et al., 2006), However, Mitchell and Stafford (2000) find that BHARs can give false impressions of the speed of price adjustment to an event. This is because return grows with the return horizon even when there is no abnormal return after the first period. Therefore, in our study, following most of the other PEAD papers, we apply the market adjusted model. 


\subsection{Regression analysis}

Following Ng et al. (2008) we test the relationship between PEAD returns, liquidity costs and other explanatory variables by estimating the following pooled multivariate analysis.

$$
\operatorname{PEAD}_{\mathrm{i}, t}=\beta_{0}+\beta_{1} U E_{i, t}+\beta_{2} \text { Illiquidity }_{i, t}+\beta_{3} \text { Vol }_{i, t}+\beta_{4} \text { Size }_{i, t}+\beta_{5} \text { StdDev }_{i, t}+\beta_{6} \text { Price }_{i, t}+\varepsilon_{\mathrm{i}, \mathrm{t} .}
$$

Where $P E A D_{i, t}$ represents either $P E A D 3$, which is the CAR from one day before the earnings announcement to one day after or PEAD60, which is the CAR from one day following the earnings announcement to 60 days post the earnings announcement for stock $i$. Independent variables include $U E_{i, t}$, defined as the earnings surprises measured by earnings expectation from a seasonal random walk model. Illiquidity ${ }_{i, t}$ is either Spread, RtoV, RtoTR, or the three spread components $(\alpha, \beta$ and $1-(\alpha+\beta))$ of the firms. $\operatorname{Vol}_{i, t}$, is the daily trading volume of stock $i$ at time $t$, Size $_{i, t}$ captures the market capitalization of firm $i$ at time $t$. StdDev $_{i, t}$, represents daily return volatility at time period $t$. Price $e_{i, t}$, is stock $i$ 's daily closing price. To facilitate the interpretation of the coefficients on the interaction terms, we follow $\mathrm{Ng}$ et al. (2008) and rank Illiquidity, Vol, Size, StdDev and Price into quintiles within each quarter. We then rescale the data to take values within the range 0 to 1 .

\section{Empirical Results}

\subsection{Descriptive statistics}

In Table 1 we compare the firm-level descriptive statistics between zero-leverage firms and all firms from the FTSE 350 . We observe that in our sample, the market capitalization of zeroleverage firms is smaller than the average level, $£ 4070$ million for zero-leverage firms as compared to $£ 4524$ million for all FTSE 350 firms. Our result is consistent with Devos et al. (2012), who provide evidence that zero-leverage firms are small. 
Furthermore, the average bid-ask spread of zero-leverage firms are 0.473 , as compared to 0.316 for all firms. This suggests that zero-leverage firms are more illiquid than all FTSE 350 firms. The average volatility of returns predicted by the standard deviation of zero-leverage companies (1.333) are higher than all firms (1.295). This is consistent with Zhang and Gregoriou (2019), which implies that zero-leverage firms have less information available due to their lower market capitalization and their scarcity of information due to their lack of exposure to debt financing.

\section{[INSERT TABLE 1 HERE]}

\subsection{Unexpected Earnings (UE) decile analysis}

To examine whether our model explains PEAD, we construct $10 U E$ portfolios in a similar vein to Foster et al. (1984). In Table 2, Panel A represents the $U E$ decile and firm characteristics. Firms in the extreme deciles (group 1 or 10) have smaller size and lower trading volume than firms in the middle deciles. For example, the average firm size of zero-leverage firms in group 1 and group 10 is $£ 2132.5$ million and $£ 2330.3$ million respectively, whereas for group 5 and 6 it is $£ 4845.9$ and $£ 4808.6$ million respectively. The average trading volume in group 1 is 4322.7 million and for group 10 the value is 4435.8 million, whereas for group 5 and 6 it is 6725.8 and 6603.2 million respectively. For all other levered FTSE 350 firms, the pattern is similar but both size and trading volume are typically larger than the zero-leverage firms. These results are consistent with Foster et al. (1984) and Bernard and Thomas (1989). The PEAD anomaly is larger for small size firms. Baker et al. (2019) mention that when firm size increases, a firm has a smaller impact on its delayed price response in the drift window. Therefore, the drift is inversely related to firm size.

The last four columns of Panel A display stock returns for each $U E$ decile. $A R 3$ is the 3-day abnormal returns around the announcement date and $A R 60$ is the 60 day abnormal returns from 
one day following the announcement date. The results show that abnormal returns increase from decile 1 to 10 . The post announcement returns are positive for firms with positive earnings surprise (group 6 to 10) and negative for firms with negative earnings surprise (group 1 to 5). For the zero-leverage sample, firms in the bottom decile generate 3-day abnormal returns of $3.58 \%$ and 60 day abnormal returns of $-5.30 \%$, whereas the top decile generate 3 -day abnormal returns of $2.48 \%$ and 60 -day abnormal returns of $4.09 \%$. This is consistent with our first hypothesis, that the PEAD anomaly exists for UK zero-leverage firms. Post announcement returns are positive for firms with positive earnings surprise, whereas firms with negative earnings surprise have negative announcement returns.

Panel $\mathrm{B}$ of Table 2 represents the $U E$ decile and stock price, bid-ask spread and spread components. The stock price is similar with firm size and trading volume, the extreme deciles group are much lower than the firms in the middle deciles. The bid-ask spread of group 1 is 1.93 for zero-leverage firms and 1.08 for all other firms, for group 5 the spread is 0.23 for zeroleverage firms and 0.20 for all other firms. This finding is similar to prior research, with zeroleverage firms facing more information asymmetry than the levered firms. This results in the illiquidity level (bid-ask spread) being much higher than the levered firms. Sorting spread decomposition according to $U E \mathrm{~s}$, we find that the extreme deciles have larger percentages of both the adverse selection and inventory holding components. This is consistent with our second hypothesis in Section 2.2. The PEAD anomaly is greater for zero-leverage firms which are smaller and more illiquid than levered firms.

Overall, the results of Table 2 indicate that zero-leverage firms face more information asymmetry than the levered firms, resulting in greater liquidity costs for zero leverage firms as opposed to all FTSE 350 firms. For zero-leverage sample firms, the firm-level variables which 
are related to liquidity and spread components form a U-shape over the magnitude of the UE level. Relating the abnormal return of sample firms in every decile with the liquidity costs, we report that the stock return in the extreme deciles also have higher liquidity costs. Relating the firm size with the effective spread deciles our findings are consistent with Bhushan (1994). This is because they establish that transaction costs are higher for small firms and this drives the sensitivity of PEAD to firm size.

\section{[INSERT TABLE 2 HERE]}

\subsection{Liquidity ratio changes around the earnings announcement period}

We construct ratios of the bid-ask spreads, the RtoV and RtoTR ratio over various event windows around the earnings announcement dates. The null hypothesis is that the ratios are equal to unity (indicating no change in the daily average time-weighted spread, RtoV, and RtoTR ratio) is tested by a standard t-test. Since bid-ask spread, RtoV and RtoTR ratios are all illiquidity ratios, an increase in the value suggests decreases of liquidity in the postannouncement period. There is clear evidence from Table 3 that illiquidity levels are significantly increased after the announcement of earnings. For example, in the $[-1,+1]$ event window, the mean of the bid-ask spread ratio is 1.65 with a highly significant t-statistic of 4.28 . It indicates that bid-ask spreads are significantly higher over the 3-trading day period centred on the announcement day. On the announcement day, the bid-ask spread ratio is 1.34 , which is larger than 1 and significantly different from zero. In all short-run event windows, all effective spreads ratios are larger than 1 and most of them are highly significant. However, earnings announcements result in an increase in spread that diminishes over 60 trading days after the earnings are announced. This is because the average bid-ask spread ratio for the long-term period, $[0,60]$ period is 0.94 and insignificant (t-statistics $=-1.26)$. 
The increase in illiquidity is also pronounced for the RtoV and RtoTR ratios. From the last four columns of Table 3, we observe that both the RtoV and RtoTR ratios show a clear increase over the event window. For example, in the $[-5,+5]$ interval the Rto $V$ and RtoTR ratio is 1.27 and 1.30 respectively. In the $[-1,+1]$ interval, the decrease is more pronounced, 1.57 and 1.49 for the RtoV and RtoTR ratios respectively, with both ratios being highly significant. On the event day, the ratios are 1.31 for $R t o V$ and 1.33 for RtoTR respectively with high levels of significance. There is some evidence of the reversal of the bid-ask spread increase in the 60day post-announcement period, but not enough to eliminate the illiquidity accrued during the event period. Our results provide clear evidence that earnings announcements decrease liquidity.

\section{[INSERT TABLE 3 HERE]}

\subsection{Spread component changes around the earnings announcement period}

In Section 2.2 we predict that the PEAD anomaly of zero-leverage firms is related with the information asymmetry. To test this hypothesis, we decompose the bid-ask spread of both zeroleverage and levered firms using the three-way Huang and Stoll (1997) model. We estimate the data 60 trading days before and after the announcement date. For comparison, we also obtain the spread decomposition for all FTSE 350 firms in the same event day. For zeroleverage firms, the estimates of the adverse selection are increasing from 0.296 before to 0.358 after the earnings announcements. The estimates of the inventory holding cost components are 0.302 in the pre to 0.299 in the post-announcement period. Panel B presents the results of all FTSE 350 firms. There are no changes for all other firms that do not have earnings announcements on that day. Since we have established that earnings announcements will lead to the increase of spreads, and the order processing costs are fixed, the increase in spreads are attributed to changes in the adverse selection component. Given that earnings announcements 
are associated with high trading volume, the bid-ask spread is widened to protect market makers against traders with superior information.

Our results are consistent with Krinsky and Lee (1996) who report that the adverse selection cost increases around earnings announcements. However, they detect the decrease of both inventory holding costs and order processing costs, whereas in our study this change is insignificant. Affleck-Graves et al. (1994) explain that the inventory holding costs may be attributed to differences in the characteristics of firms that choose to list on a trading system. Our empirical estimates are based on the UK equity market as opposed to the US results obtained from Krinsky and Lee (1996), which could explain the difference in our findings.

\section{[INSERT TABLE 4 HERE]}

\subsection{Regression test of PEAD against determinants of zero-leverage firms by liquidity costs}

Following $\mathrm{Ng}$ et al. (2008), we obtain the earnings response coefficient regressions to examine the effect of the liquidity costs on the PEAD for earnings surprises. Our general regression specification is equation (10) in Section 4.4. In our regression model we use two alternative definitions of market-adjusted returns. First we use PEAD3 which is a 3-day short window, focused on the earning announcement date. Second, we utilize PEAD60 defined as a 60-day long event window from the second day to 60 days after the earnings announcement as our measure of the drift. The $U E$, earnings surprise is calculated using equation (1), and other variables are the same as we have defined in Section 4.4. To reduce the outliers effect, we rank our variables into quintiles within each calendar quarter and rescale the data to range from 0 to 1. The results are shown in Table 5 .

Our primary focus is on each liquidity cost. Overall, in table 5, the PEAD3 models have much smaller and insignificant results for most variables. For example, for the spread model the 
coefficient of $U E$ for the PEAD3 model is much small than the PEAD60 model (0.004 with a t-statistics of 1.29 versus 2.128 with a t-statistic of 3.45$)$. This is consistent with the previous studies (e.g. $\mathrm{Ng}$ et al., 2008), since PEAD3 includes the earnings announcement date, severe measurement error problems occur on that event date. Berkman and Truong (2009) document that in recent years (after 2000), more than $40 \%$ of earnings announcements are made after the closing of trading. It leads to the stock price, trading volume and volatility being biased on the event day (day 0). The largest changes of price and trading volume in reaction to earnings are observed on the first day subsequent to the earnings announcement date. The PEAD60, which are calculated from the second day post the earnings announcement period avoid this problem. Especially, for firms with a poorer information environment and higher transaction costs such as zero-leverage firms, the noise in the earnings expectation model is more transparent. Moreover, the coefficient on the bid-ask spread is -0.056 for the regression model of PEAD3 and -2.130 for the regression model of PEAD60. Also, only the PEAD60 model reports significant bid-ask coefficients at the $1 \%$ level. The bias in the PEAD3 model causes some peculiar predictions on liquidity costs. For example, the coefficient of $U E^{*} R t o V$ is 0.011 and $U E^{*}$ RtoTR is 0.009 , with both insignificant. Turning to the PEAD60 model, the last two columns of Table 5 shows that all the results of liquidity costs variables are consistent with our predications that higher liquidity costs are associated with lower earnings response after the announcement. The results suggest that the liquidity costs not measured by the bid-ask spread, $U E^{*} R$ to $V$ and $U E^{*}$ RtoTR ratio have a significant effect on the PEAD.

A surprising result from Table 5 is the insignificant and small coefficient for firm size variables (for example, in the spread model of panel A, the coefficient is -0.010 for the PEAD3 model and -0.003 for the PEAD60 model). The size phenomenon (e.g. the U-shape relation between drift and firm size which we indicated in Section 5.2) disappears after we control for other 
variables. Truong (2010) examines the PEAD anomaly in New Zealand via a group of firms which have reasonably large market capitalisation and the size effect is not revealed. Similarly, we can explain the insignificant relation between size and drift as our sample firms are generally small, leading to the size effect being less significant than previous studies. Like the results in $\mathrm{Ng}$ et al. (2008), the coefficient of price is insignificant for zero-leverage firms. Hence, there is no evidence that stock prices impede activity of PEAD in zero-leverage firms. These results could be attributed to our sample of zero-leverage firms which generally have lower stock prices than levered firms.

For measuring how the different leverage level effect on the PEAD anomaly to the same firm, we subsample the zero-leverage firms which are levered up by seeking the bank loan during our sample period. The initial loan announcement of zero-leverage firms is a positive signal from the bank and financial market and can help to relieve the information asymmetry problems. After the initial loan announcement, the zero-leverage firms start to build up their credit history and are monitored by financial institutions. At the same time, they attract more attention from the analysts and market agents. Therefore, we choose the quarterly earnings announcement for the same sample firms when they are issued the initial loan from the bank. We re-examine the regression between PEAD and liquidity costs during the post initial loan announcement period for zero-leverage firms, and the results are reported in Panel B of Table 5.

From Panel B, we can see that the variables of liquidity costs continue to explain the PEAD even after the zero-leverage entry into the debt market. There is an important finding to be noted from the results. The difference between the coefficients of the PEAD3 and PEAD60 models are smaller than the pre-initial loan period. This reflects the improvement of the 
information environment when the zero-leverage firms build the credit relationship with the financial institution.

For other variables, Panel B are similar to the findings in Panel A. Trading volumes are inversely related with the drift return and the price coefficients remain insignificant. This result consistent with Bhushan (1994), supports that the drift is larger for illiquid stocks. One interesting point is that the magnitude of the firm size coefficients are significantly enhanced after the zero-leverage firms obtain the loan from the bank. This could be because when firms borrow funds they are able to use the additional resource to grow, leading to increases in market capitalization.

\section{[INSERT TABLE 5 HERE]}

\subsection{Regression test of PEAD against determinants of zero-leverage firms by spread decomposition}

In table 6, we re-examine our general regression specification of equation (10), using the spread decomposition components as liquidity costs variables. The results of pre-levering up period are reported in Panel A whereas the post-levering up period are reported in Panel B. Panel A shows that the coefficients on $U E^{*}$ adverse selection are -0.032 and -3.457 for the regressions of PEAD3 and PEAD60 respectively. It suggests that after controlling for other firms' characteristics, the adverse selection costs are negatively related with PEAD in both the short and long run. Table 6 also reports that there is no relation between drift and inventory holding and order processing costs. This implies that information asymmetry is driving the PEAD rather than changes in inventory holding and order processing costs. The lack of relation between drift and order processing costs supports the fact that PEAD is mainly due to the information environment. 
Similar with table 5, the coefficients of the size variables are insignificant and small in all models shown in Panel A, the only exception is the inventory holding model in PEAD3. For example, for the adverse selection model, before initial loan announcement, the coefficient is -0.013 for the PEAD3 model and -0.007 for the PEAD60 model. Whereas in the post initial loan announcement in Panel $\mathrm{B}$, the coefficient of $U E^{*}$ Size is statistically significant with coefficients of -0.236 for $P E A D 3$ and -0.203 for PEAD60. This indicates that the size phenomenon which disappears in the pre-initial loan announcement period is enhanced during the post-initial loan announcement period. The levering up of zero-leverage firms has an overall impact on the post earnings stock performance.

Tables 5 and 6 show evidence that drift is negatively related to trading volume. All the coefficients associated with trading volume are highly significant, and the PEAD3 models produce more powerful tests. For example, in the adverse selection model in panel A of table 6, the coefficient of volume is -1.613 for the PEAD3 model and -0.804 for the PEAD60 model. This shows that on the announcement date, trading volumes are changing dramatically and possess a powerful effect on the return.

\section{[INSERT TABLE 6 HERE]}

\subsection{Regression test of PEAD against determinants of levered firms}

As we mentioned before there are no previous studies focusing on the liquidity level and PEAD returns around the earnings announcements in the UK market. In order to fill this gap in the literature, in Table 7 we compute equation (10) for all levered firms listed on the FTSE350 index during our sample period. In table 7, we divide our five liquidity cost measurements into two panels. The bid-ask spread, RtoV and RtoTR model in Panel A, and the three spread components model in Panel B. 
Similar with the results of zero-leverage firms, the $U E$ results for the 3-day event window are less powerful than the 60-day event window in both Panel A and Panel B. This implies that for all levered firms, the measurement error problem in the event day still exists as mentioned in Berkman and Truong (2009). In the spread model, the coefficients of $U E$ and PEAD are estimated as 0.025 for $P E A D 3$ and 1.306 for PEAD60, with t-statistics equals to 1.46 and 3.49 respectively, with only the PEAD60 model reporting significance at the $1 \%$ level. In the RtoV model, the coefficient is 0.016 for the three-day window and 1.457 for the 60 -day window. Once again, only the PEAD60 model displays significant at the $1 \%$ level. Comparing with the results in Table 5 and 6 , we can see that the coefficients of PEAD3 for levered firms are significantly larger than the zero-leverage firms. This indicates that for levered firms, the noise in the earnings expectation model is less pronounced.

The UE*Spread coefficient in Panel A, is -0.014 with a t-test equal to 1.33 for PEAD3 (not significant) and -1.646 with a t-test equal to 3.77 (significant at the $1 \%$ level). This suggests that the higher liquidity costs are associated with lower earnings response after the announcement. The $U E^{*}$ Rto $V$ and $U E^{*}$ RtoTR are also negatively related to PEAD return in both the short and long term. Turning to the spread decomposition and drift return, we discover that firms inventory holding costs and order processing costs are unrelated with the PEAD return, which is similar to the zero-leverage firms. Based on the Huang and Stoll three spread decomposition model, the only components which contributed to the return drift around the earnings announcement is the adverse selection costs. Comparing the zero-leverage firm results in our study, the coefficients of liquidity costs of levered firms are much smaller than the coefficients of zero-leverage firms. The gap between PEAD3 and PEAD60 are not as wide as zero-leverage firms. This is consistent with our second hypothesis, that the drift anomaly in zero-leverage firms post earnings announcement period is greater than the levered firms. 
The coefficients of firm size are larger and more significant for levered firms. For example, in the spread model of Panel A, the coefficients on $U E^{*}$ Size are -0.248 and -0.203 for PEAD3 and PEAD60 respectively, with both being significant at the $10 \%$ level. The coefficient of stock price still small and insignificant for levered firms, 0.021 for PEAD3 and 0.020 for PEAD60.

\section{[INSERT TABLE 7 HERE]}

\subsection{Robustness test: PEAD against determinants in different event windows}

To assess the robustness of our liquidity costs and PEAD explanation, we study the effects of liquidity costs for alternative event windows in both the short and long-run. We re-estimate our regression model for different event windows between 1 day before the event announcement until 40 days after the announcement. We define PEAD5 as $(-2,+2)$ event window around the earnings announcement to examine if the measurement errors which happened during the event day still exist. We also compute PEAD10, PEAD20, PEAD40 as $(+1,10),(+1,20)$ and $(+1$, +40 ) event periods for robustness, starting from 1 day after the event announcement to avoid any possible measurement error. The results are reported in Table 8.

From Table 8 we can see that there is a clear evidence that the measurement error in the event day is still presents at the $(-2,+2)$ event period. For example, the coefficient of $U E$ and PEAD5 are $0.016,0.017$ and 0.022 for spread, RtoV, and the RtoTR model respectively. Whereas in the next columns the coefficient between $U E$ and PEAD10 increases dramatically, with 0.948 , 0.754 and 0.609 respectively, all of them being significant at the $10 \%$ level. From event window $(+1,+10)$, the association between the earnings surprise (UE) and PEAD return is significant for all return intervals and the estimated returns are increasing in magnitude.

Most of results in table 8 are similar with our previous findings. In Panel B of Table 8 , the coefficients on $U E^{*}$ adverse selection are $-0.917,-1.349,-2.074$ and -2.930 , for the regressions 
of PEAD5, PEAD10, PEAD20 and PEAD40 respectively. The increasing coefficient shows that the negative relation between information costs and drift return becomes more significant in the long run, after controlling for other firms' characteristics. Table 8 confirms that there is no relation between drifts, inventory holding and order processing costs. This implies that information asymmetry is driving the PEAD rather than changes in inventory holding and order processing costs.

\section{[INSERT TABLE 8 HERE]}

\section{9: Robustness test: Regression test of PEAD using different definitions of zero-leverage} firms.

We define zero-leverage firms as companies that do not have any long-term or short-term debt over our sample period. However, there are some other definitions of zero-leverage firms. For example, Streabulaev and Yang (2013) define zero-leverage firms as companies that have zero debt in a given year. Devos et al. (2012) define zero-leverage firms as companies with no debt in three consecutive years. For robustness, we re-estimate our empirical results using both these alternative definitions of zero-leverage firms ${ }^{5}$. The results are reported in Table 9.

Table 9 indicates that the results are quantitively similar regardless of how zero-leverage firms are defined. For both the Strebulaev and Yang (2013) and Devos et al. (2012) group, once again the 3-day test in the first two columns produces less powerful tests. For Strebulaev and Yang (2013), the coefficient on the bid-ask spread is -0.108 for the PEAD3 model and -1.917 for the regression models of PEAD60. Only the PEAD60 model reports significant coefficients at the $1 \%$ level. For Devos et al. (2012), the coefficients are -0.063 and -2.276 respectively. Table 9

\footnotetext{
${ }^{5}$ Overall, based on our previous data selection requirement, there are 164 zero-leverage firms according to the Strebulaev and Yang definition, and there are 121 sample firms which meet the definition of Devos et al. (2012).
} 
confirms the previously documented insignificant relation between size and PEAD. Trading volume is highly significant in the 3 -day window models, but weaker in the $(+1,+60)$ event period. The stock price variables are still not significant in these multiple regressions.

\section{[INSERT TABLE 9 HERE]}

\section{Conclusion}

In this study we investigate how liquidity costs are related with PEAD. Using a sample of 93 zero-leverage firms listed on the FTSE 350 index over the time period of 2000-2015, we discover that illiquidity levels are significantly increased around the earnings announcement period. The bid-ask spreads are widened, and price impact (illiquidity) ratios (RtoV, and RtoTR) all rise in the post earnings announcement period. Once we decompose the bid-ask spread components during the earnings announcements, we observe that the adverse selection costs are significantly enhanced, whereas the inventory holding and order processing costs are unchanged. We conclude that the PEAD anomaly is related with information asymmetry for zero-leverage firms. In addition, using regression analysis, we show that firms with higher liquidity costs exhibit greater abnormal returns. This suggests that greater PEAD is related with higher liquidity costs and vice versa. Our results are robust to alternative event windows and definitions of zero-leverage firms. Dividing the data into positive and negative earnings surprises for zero leverage firms would be an interesting avenue for further research. 


\section{References}

Affleck-Graves,J., Hedge, S.P., and Miller, R.E., (1994), "Trading mechanisms and the components of the bid-ask spread", Journal of Finance, Vol.49, pp.1471-1488.

Alwathnani, A.M., Dubofsky, D.A., and Al-Zoubi, H., (2017), "Under-or-overreaction: Market responses to announcements of earnings surprises", International Review of Financial Analysis, Vol. 52, pp. 160-171.

Amihud, Y., (2002), "Illiquidity and stock returns: Cross-section and time-series effects", Journal of Financial Markets, Vol.5, pp, 31-56.

Ariff, M., Loh, A., and Chew,P., (1997), "The impact of accounting earnings disclosures on stock prices in Singapore", Asia Pacific Journal of Management, Vol.14, pp.17-29.

Baker, K., Ni,Y., Saadi, S., and Zhu, H.M., (2019), "Competitive earnings news and postearnings announcement drift", International Review of Financial Analysis, Vol.63, pp.331343.

Ball, R., and Brown, P., (1968), "An empirical evaluation of accounting income numbers", Journal of Accounting Research, Vol. 6(2), pp.159-178.

Ball , R., (1992), “The earnings price anomaly”, Journal of Accounting and Economics, Vol.15, pp.319-345.

Bartov, E., Radhakrishnan,S., and Krinsk,I., (2000),"Investor Sophistication and Patterns in Stock Returns after Earnings Announcements”, Accounting Review, Vol.75(1), pp.43-63.

Berkman, H., and Truong, C., (2009), "Event day 0? After-hours earnings announcements", Journal of Accounting Research, Vol.47(1), pp.71-103.

Bernard, V.L., and Thomas, J.K., (1989), "Post-earnings accouchements drift: Delayed price response or risk premium?", Journal of Accounting Research, Vol.27, pp.1-36.

Bhushan, R., (1994), "An informational efficiency perspective on the post-earnings announcement drift", Journal of Accounting and Economics, Vol.18, pp.45-65.

Brown.S., Hillegeist,S.A., and Lo, K., (2009), "The effect of earnings surprises on information asymmetry", Journal of Accounting and Economics, Vol.47, pp.208-225.

Brown, R. I., and Warner, J.B., (1980), "Measuring Security Price Performance", Journal of Financial Economics, Vol.8, pp.205-258.

Cao,S.S.,and Narayanamoorthy,G.S.,(2012),"Earnings volatility, post-earnings announcement drift, and trading frictions", Journal of Accounting Research, Vol.50(1), pp.41-74.

Chordia, T., Huh, S.W., and Subrahmanyam, A., (2009), "Theory-based illiquidity and asset pricing”, Review of Financial Studies, Vol.22, pp.3629-3668. 
Chung, D.Y., and Hrazdil, K., (2011), "Market Efficiency and the post-earnings announcement drift”, Contemporary Accounting Research, Vol.28(3), pp.926-956.

Dang,V.A., (2013), “An empirical analysis of zero-leverage firms: New evidence from the UK”, International Review of Financial Analysis, Vol.30, pp.189-202.

Dargenidou,C., Tonks, I., and Tsoligkas, F., (2018), "Insider trading and the post-earnings announcement drift", Journal of Business Finance and Accounting, Vol.45(3-4), pp.482-508.

Devos,E., Dhillon, U., Jagannathan,M., and Krishnamurthy,S., (2012), "Why are firms unlevered?", Journal of Corporate Finance, Vol.18, pp.664-682.

Dichev, I.D., and Tang, V.W., (2009), "Earnings volatility and earnings predictability", Journal of Accounting and Economics, Vol. 47, pp.160-181.

Doyle, J.T., Lundholm, R.J., and Soliman, M.T., (2006), "The extreme future stock returns following I/B/E/S earnings surprises", Journal of Accounting Research, Vol.44(5), pp.849886.

Easterwood, J., and Nutt,S., (1999), "Inefficiency in analysts' earnings forecast: Systematic miserection or systematic optimism?” Journal of Finance, Vol.54(5), pp.1777-1797.

Eom, Y., Hahm, J., and Sohm, W., (2019), "Individual investors and post-earningsannouncement drift: Evidence from Korea”, Pacific-Basin Finance Journal, Vol.53, pp.379398.

Fama, E.F., (1998), "Market efficiency, long-term returns, and behavioural finance”, Journal of Financial Economics, Vol.49, pp.283-306.

Faulkender, M., and Petersen, M.A., (2006), "Does the source of capital affect capital structure?" Review of Financial Studies, Vol.19(1), pp.45-79.

Florackis,C., Gregoriou, A., and Kostakis, A., (2011), "Trading frequency and asset pricing on the London Stock Exchange: Evidence firm a new price impact ratio", Journal of Banking and Finance, Vol.35(12), pp.3335-3350.

Foster,G., Olsen,C., and Shevlin,T., (1984), "Earnings releases, anomalies, and the behaviour of security returns”, Accounting Review, Vol.59(4), pp.574-604.

Forner,C., and Sanabria, S., (2010), "Post earnings announcement drift in Spain and behavioural finance models", European Accounting Review, Vol.19, pp.775-815.

Francis, F., Lafond, R., Olsson, P., and Schipper, K., (2007), "Information uncertainty and post earnings announcement drift", Journal of Business Finance and Accounting, Vol.34 (3-4), pp. 403-433.

Hew, D., Skerratt, L., Strong, N., and Walker, M., (1996), "Post earnings announcement drift: Some preliminary evidence for the UK", Accounting and Business Research, Vol.26(4), pp.283-293. 
Hirshleifer, D., Lim, S.S., and Teoh, S.H., (2009), "Driven to distraction: Extraneous events and underreaction to earnings news", Journal of Finance, Vol.64, pp.2289-2325.

Huang, R.D. and Stoll, R.S.,(1997), "The components of the bid-ask spread: A general approach”, Review of Financial Studies, Vol.10, pp.995-1034.

Imhoff, E., and Lobo, G., (1992), "The effect of ex ante earnings uncertainty on earnings response coefficients", Accounting Review, Vol.67, pp.427-439.

Jones, C.P., and Litzenberger, R.H., (1970), "Quarterly earnings reports and intermediate stock price trends", Journal of Finance, Vol.25(1), pp.143-148.

Kaniel, R., Liu, S., Saar, G., and Sheridan, T., (2012), "Individual investor trading and return patterns around earnings announcements", Journal of Finance, Vol.67(2), pp.639-680.

Krinsky.,I. and Lee, J., (1996), "Earnings announcements and the components of the bid-ask spread", Journal of Finance, Vol.51(4), pp.1523-1535.

Kim, D., and Kim, M., (2003), "A multifactor explanation of post-earnings announcement drift”, Journal of Financial and Quantitative Analysis, Vol.38(2), pp.383-398.

Laidroo, L., and Grigaliuniene, Z., (2014), "Testing for asymmetries in price reactions to quarterly earnings announcements on Tallinn, Riga and Vilnius stock exchanges during 20002009”, Baltic Journal of Economics, Vol.12(1), pp.61-86.

Liang, L., (2003), "Post-earnings announcement drift and market participants' information processing biases", Review of Accounting Studies, Vol.8(2-3), pp.321-345.

Livnat, J., and Mendenhall, R.R., (2006), "Comparing the post earnings announcement drift for surprises calculated from analyst and time series forecasts", Journal of Accounting Research, Vol.44(1), pp.175-205.

Liu,W., Norman,S., and Xinzhong, X., (2003), "Post earnings announcement drift in the UK", European Financial Management, Vol.9(1), pp.89-116.

Madhavan, A., Richardson, M. and Roomans, M., (1997), "Why do security prices change? A Transaction -Level analysis of NYSE stocks", Review of Financial Studies, Vol.10, pp.10351064.

Mitchell, M.L., and Stafford, E., (2000), "Managerial decisions and long-term stock price performance", Journal of Business, Vol.,73(3), pp.287-329.

Ng. J., Rusticus, T., and Verdi, R., (2008), "Implications of transaction costs for the postearnings announcement drift", Journal of Accounting Research, Vol.46(3), pp.661-696.

Park, T., Lee, Y., and Song, K., (2014), "Informed trading before positive vs. negative earnings surprises", Journal of Banking and Finance, Vol.49, pp.228-241.

Sadka, R., (2006), "Momentum and post-earnings-announcement drift anomalies: The role of liquidity risk", Journal of Financial Economics, Vol.80(2), pp.309-349. 
Son, D.H., Palmon, D., and Yezegel, A., (2018), "The persistence of firm-specific postearnings announcement returns", Investment Analysts Journal, Vol.47(1), pp.31-47.

Strebulaev, I.A., and Yang, B., (2013), “The mystery of zero-leverage firms”, Journal of Financial Economics, Vol.109 (1), pp.1-23.

Slovin, M., Johnson, S., and Glascock, J., (1992), "Firm size and the information content of bank loan announcements”, Journal of Banking and Finance, Vol.16, pp.1057-1071.

Van Huffel, G., Joos, P., and Ooghe, H., (1996), "Semi-annual earnings announcements and market reaction: Some recent findings for a small capital market", European Accounting Review, Vol.5, pp.693-713.

Vega, C. (2006), "Stock price reaction to public and private information", Journal of Financial Economics, Vol.82(1), pp.103-133.

Truong,C., (2010), "Post earnings announcement drift and the roles of drift-enhanced factors in New Zealand”, Pacific-Basin Finance Journal, Vol.18, pp.139-157.

Truong,C., (2011), "Post-earnings announcement abnormal return in the Chinses equity market”, International Financial Market Institution and Money, Vol.21, pp.637-661.

Zhang, Q.,Cai, C.X., and Keasey, K., (2013). "Market reaction to earnings news: A unified test of information risk and transaction costs", Journal of Accounting and Economics, Vol.56(2-3), pp.251-66.

Zhang, S., and Gregoriou, A., (2019), "Initial bank loans, zero-Leverage firms and stock market liquidity: New empirical evidence from the UK", Journal of Economic Studies, Vol.5, pp.1028-1051. 


\section{Table 1: Descriptive statistics}

Table 1 provides the descriptive statistics for the data sample. The sample consists of 93 zero-leverage firms listed on the FTSE 350 during the time period of 2000-2015, and all levered FTSE 350 firms. Market capitalization is calculated as the share price multiplied by the number of shares traded. Stock price is the stock $i$ 's daily closing price. Trading volume data is taken directly from the database. Effective spread is defined as two times trade price minus quote midpoint, the midpoint is ask price minus bid price divided by two.

\begin{tabular}{|c|c|c|}
\hline & ZERO-LEVERAGE FIRM (NO.=93) & $\begin{array}{l}\text { ALL LEVERED FIRMS } \\
\text { (NO.=251) }\end{array}$ \\
\hline $\begin{array}{l}\text { MARKET } \\
\text { CAPITALIZATION } \\
\text { (ફMILLION) }\end{array}$ & 4070 & 4524 \\
\hline STOCK PRICE (£) & 526.0 & 599.3 \\
\hline $\begin{array}{l}\text { STANDARD } \\
\text { DEVIATION OF } \\
\text { RETURN (\%) }\end{array}$ & 1.333 & 1.295 \\
\hline $\begin{array}{l}\text { TRADING VOLUME } \\
\text { (MILLION) }\end{array}$ & 6324 & 6730 \\
\hline $\begin{array}{l}\text { EFFECTIVE SPREAD } \\
(\%)\end{array}$ & 0.473 & 0.316 \\
\hline
\end{tabular}




\section{Table 2: Characteristics of UE deciles}

Panel A of Table 2 presents the firm level characteristics and abnormal returns for each unexpected earnings (UE) decile for both zero-leverage and all levered FTSE350 firms. Panels B presents the spread decomposition for each $U E$ decile. Firms are assigned into $U E$ decile portfolios based on the distribution of $U E$ in the prior fiscal quarter. Firm size is the market value of sample firms at the earnings announcement month. Trading volume is the average daily trading volume during the announcement month. $A R 3$ is the 3 -day abnormal returns around the earnings announcement and AR60 is the 60 days abnormal returns from one day following the earnings announcement. Price is the average closing daily price during the announcement month. Spread is the average daily effective spread which is calculated as twice the absolute value of the actual execution price minus the mid-point of the quoted bid-ask spread immediately before the transaction. The adverse selection $(\alpha)$, inventory costs components $(\beta)$ is estimated by the Huang and Stoll (1997) three-way decomposition model. ${ }^{* * *}$ denotes significance at $1 \%,{ }^{* *}$ denotes significance at $5 \%$ and ${ }^{*}$ denotes significance at $10 \%$.

Panel A: Firm characteristics and abnormal returns

\begin{tabular}{|c|c|c|c|c|c|c|c|c|}
\hline \multirow[t]{2}{*}{ Decile } & \multicolumn{2}{|c|}{ Firm size(£million) } & \multicolumn{2}{|c|}{ Trading volume(million) } & \multicolumn{2}{|c|}{ AR 3(\%) } & \multicolumn{2}{|c|}{ AR $60(\%)$} \\
\hline & ZL firms & L firms & ZL firms & L firms & ZL firms & $\mathrm{L}$ firms & ZL firms & L firms \\
\hline 1 & 2132.5 & 2824.0 & 4322.7 & 4526.4 & -3.58 & -2.05 & -5.30 & -2.98 \\
\hline t-stat & & & & & $-22.6^{* * *}$ & $-18.9^{* * *}$ & $-29.3^{* * *}$ & $-21.2^{* * *}$ \\
\hline 2 & 2680.1 & 3236.8 & 4896.1 & 4903.7 & -2.34 & -1.11 & -2.37 & -1.25 \\
\hline t-stat & & & & & $-19.3^{* * *}$ & $-16.3^{* * *}$ & $-20.2^{* * *}$ & $-16.4^{* * *}$ \\
\hline 3 & 3499.4 & 3874.1 & 5531.4 & 5908.2 & -0.85 & -0.61 & -0.99 & -0.87 \\
\hline t-stat & & & & & $-14.8^{* * *}$ & $-14.2^{* * *}$ & $-15.6^{* * *}$ & $-15.0^{* * *}$ \\
\hline 4 & 4032.0 & 4408.4 & 6636.6 & 6926.5 & -0.56 & -0.27 & -0.74 & -0.59 \\
\hline t-stat & & & & & $-31.7^{* * *}$ & $-12.9^{* *}$ & $-14.4^{* * *}$ & $-13.9^{* * *}$ \\
\hline 5 & 4845.9 & 5037.5 & 6725.8 & 7530.7 & -0.33 & -0.15 & -0.65 & -0.33 \\
\hline t-stat & & & & & $-13.2^{* * *}$ & $-12.3^{* *}$ & $-14.5^{* * *}$ & $-13.3^{* * *}$ \\
\hline 6 & 4808.6 & 5142.3 & 6603.2 & 7399.1 & 0.48 & 0.62 & 0.82 & 1.11 \\
\hline t-stat & & & & & $13.6^{* * *}$ & $14.5^{* * *}$ & $-15.5^{* * *}$ & $16.2^{* * *}$ \\
\hline 7 & 4231.3 & 4899.3 & 5218.9 & 6938.9 & 0.76 & 1.33 & 1.59 & 1.78 \\
\hline t-stat & & & & & $14.5^{* * *}$ & $16.4^{* * *}$ & $17.1^{* * *}$ & $15.7^{* * *}$ \\
\hline 8 & 3244.1 & 4407.6 & 4934.7 & 5827.6 & 1.03 & 1.96 & 2.43 & 2.64 \\
\hline t-stat & & & & & $15.9^{* * *}$ & $17.4^{* * *}$ & $19.9^{* * *}$ & $21.2^{* * *}$ \\
\hline 9 & 2908.9 & 3988.5 & 4014.5 & 5104.8 & 1.90 & 2.38 & 3.84 & 3.99 \\
\hline t-stat & & & & & $16.7^{* * *}$ & $18.7^{* * *}$ & $23.1^{* * *}$ & $24.3^{* * *}$ \\
\hline 10 & 2330.3 & 3271.4 & 4435.8 & 4980.4 & 2.48 & 2.95 & 4.09 & 4.37 \\
\hline t-stat & & & & & $20.6^{* * *}$ & $21.9^{* * *}$ & $26.8^{* * *}$ & $27.2^{* * *}$ \\
\hline
\end{tabular}

\begin{tabular}{|c|c|c|c|c|c|c|c|c|}
\hline \multicolumn{9}{|c|}{ Panel B: Price, spread and spread decomposition } \\
\hline \multirow[t]{2}{*}{ Decile } & \multicolumn{2}{|c|}{ Price } & \multicolumn{2}{|c|}{ Spread } & \multicolumn{2}{|c|}{ Adverse selection } & \multicolumn{2}{|c|}{ Inventory holding } \\
\hline & ZL firms & L firms & ZL firms & L firms & ZL firms & L firms & ZL firms & L firms \\
\hline 1 & 358.0 & 373.4 & 1.93 & 1.08 & 0.435 & 0.423 & 0.313 & 0.317 \\
\hline t-stat & & & 8.2 & 5.3 & $13.6^{* * *}$ & $13.6^{* * *}$ & $13.1^{* * *}$ & $13.3^{* * *}$ \\
\hline 2 & 432.5 & 472.9 & 1.48 & 0.96 & 0.387 & 0.315 & 0.314 & 0.321 \\
\hline t-stat & & & 6.5 & 5.2 & $13.4^{* * *}$ & $13.0^{* * *}$ & $13.1^{* * *}$ & $14.2^{* * *}$ \\
\hline 3 & 498.4 & 523.7 & 0.65 & 0.53 & 0.389 & 0.298 & 0.285 & 0.291 \\
\hline t-stat & & & 4.3 & 4.0 & $13.4^{* * *}$ & $12.9^{* * *}$ & $13.0^{* * *}$ & $11.0^{* * *}$ \\
\hline 4 & 563.0 & 584.6 & 0.34 & 0.29 & 0.314 & 0.249 & 0.280 & 0.263 \\
\hline t-stat & & & 3.0 & 2.8 & $13.1^{* * *}$ & $12.7^{* * *}$ & $12.9^{* * *}$ & $10.9^{* * *}$ \\
\hline 5 & 659.5 & 692.7 & 0.23 & 0.20 & 0.211 & 0.204 & 0.249 & 0.234 \\
\hline t-stat & & & 2.6 & 2.1 & $12.3^{* * *}$ & $12.3^{* * *}$ & $12.8^{* * *}$ & $10.7^{* * *}$ \\
\hline 6 & 628.4 & 690.8 & 0.22 & 0.19 & 0.204 & 0.200 & 0.258 & 0.225 \\
\hline t-stat & & & 2.4 & 1.7 & $12.1^{* * *}$ & $12.3^{* * *}$ & $12.8^{* * *}$ & $9.4^{* * *}$ \\
\hline 7 & 574.8 & 615.3 & 0.48 & 0.35 & 0.355 & 0.245 & 0.266 & 0.239 \\
\hline t-stat & & & 3.5 & 3.2 & $13.1^{* * *}$ & $12.7^{* * *}$ & $12.9^{* * *}$ & $10.8^{* * *}$ \\
\hline 8 & 532.5 & 572.9 & 0.76 & 0.68 & 0.374 & 0.294 & 0.298 & 0.301 \\
\hline t-stat & & & 4.9 & 4.7 & $13.4^{* * *}$ & $12.8^{* * *}$ & $13.0^{* * *}$ & $12.2^{* * *}$ \\
\hline 9 & 439.9 & 480.4 & 1.27 & 1.03 & 0.358 & 0.307 & 0.307 & 0.304 \\
\hline t-stat & & & 5.5 & 5.0 & $13.3^{* * *}$ & $12.9^{* * *}$ & $13.0^{* * *}$ & $12.7^{* * *}$ \\
\hline 10 & 398.6 & 431.1 & 1.84 & 1.46 & 0.418 & 0.325 & 0.316 & 0.309 \\
\hline t-stat & & & 7.9 & 6.4 & $13.5^{* * *}$ & $13.1^{* * *}$ & $13.1^{* * *}$ & $13.3^{* * *}$ \\
\hline
\end{tabular}




\section{Table 3 Liquidity ratio changes around the earnings announcement period}

Table 3 provides the robustness test for liquidity between the pre and post earnings announcement period. The sample consists of 93 zero-leverage firms listed on the FTSE 350 during the time period of 2000-2015.Illiquidity is measured by the Spread, RtoV and RtoTR ratio. Bid-ask spread is calculated as twice the absolute value of the actual execution price minus the mid-point of the quoted bid-ask spread immediately before the transaction. Rto $V$ ratio is defined as the average daily absolute stock return to its trading volume. RtoTR ratio is defined as the average daily absolute stock return to its turnover. The null hypothesis is that the mean of the reported ratio is equal to unity and is tested using a standard t-test. ${ }^{* * *}$ denotes significance at the $1 \%,{ }^{* *}$ denotes significance at the $5 \%$ and ${ }^{*}$ denotes significance at the $10 \%$.

\begin{tabular}{lcccccc}
\multicolumn{1}{r}{$\mathrm{ES}_{\mathrm{i}, \mathrm{t}}=2\left|\mathrm{P}_{i, t}-\mathrm{Mid}_{i, t}\right|$} & $\mathrm{RtoV}_{\mathrm{i}}=\frac{1}{\mathrm{D}_{i}} \sum_{d=1}^{\mathrm{D}_{i}} \frac{\left|\mathrm{R}_{i, d}\right|}{\operatorname{Vold}_{i, d}}$ & $\operatorname{RtoTR}_{\mathrm{i}}=\frac{1}{\mathrm{D}_{i}} \sum_{d=1}^{\mathrm{D}_{i}} \frac{\left|\mathrm{R}_{i, d}\right|}{\mathrm{TR}_{i, d}}$ & \\
Event day & Spread & T-test & $\mathbf{R t o V}$ & T-test & RtoTR & T-test \\
$\mathbf{0}$ & 1.34 & $4.19^{* * *}$ & 1.31 & $2.99^{* *}$ & 1.33 & $3.08^{* *}$ \\
$\mathbf{( - 1 , + 1 )}$ & 1.65 & $4.28^{* * *}$ & 1.57 & $3.28^{* * *}$ & 1.49 & $2.87^{* *}$ \\
$\mathbf{( - 2 , + 2 )}$ & 1.17 & $2.74^{* *}$ & 1.33 & $2.25^{* *}$ & 1.58 & $3.14^{* *}$ \\
$\mathbf{( - 5 , + 5 )}$ & 1.36 & $2.33^{*}$ & 1.27 & $2.04^{*}$ & 1.30 & $2.61^{* *}$ \\
$\mathbf{( - 1 0 , 1 0 )}$ & 1.45 & $2.89^{* *}$ & 1.34 & $2.48^{* *}$ & 1.06 & $1.94^{*}$ \\
$\mathbf{( 0 , + 6 0 )}$ & 0.94 & -1.26 & 0.96 & $-1.84^{*}$ & 1.05 & $-1.84^{*}$
\end{tabular}

Table 4. Spread components for zero-leverage firms and levered FTSE 350 firms using the threeway Huang and Stoll model

Table 4 reports a comparison of the bid-ask spread components of zero-leverage firms before and after the earnings announcement. The sample consists of 93 zero-leverage firms listed on the FTSE 350 during the time period of 2000-2015. The Table also reports the bid-ask spread components for all levered FTSE 350 firms during the same event period. The adverse selection $(\alpha)$ and inventory costs components $(\beta)$ is estimated by the Huang and Stoll (1997) three-way decomposition model. We estimate the data 60 trading days before and after the announcement date. Two tailed tests of significance are reported as follows, ${ }^{* * *}$ denotes significance at $1 \%,{ }^{* *}$ denotes significance at $5 \%$ and ${ }^{*}$ denotes significance at $10 \%$.

\section{Zero-leverage firms}

$\begin{array}{ll}\boldsymbol{\alpha}_{\mathrm{i}}(\mathbf{\%}) & \text { Before } \\ \boldsymbol{\beta}_{\mathrm{i}}(\%) & 0.296 \\ & 0.302\end{array}$

\section{All levered firms}

$\begin{array}{ll}\boldsymbol{\alpha}_{\mathrm{L}}(\%) & 0.251 \\ \boldsymbol{\beta}_{\mathrm{L}}(\%) & 0.314\end{array}$

$\begin{array}{lll}\text { T-stat } & \text { After } & \text { T-stat } \\ 18.11^{* * *} & 0.358 & 11.26^{* * *} \\ 18.76^{* * *} & 0.299 & 22.66^{* * *}\end{array}$

$\begin{array}{lll}\text { T-stat } & \text { After } & \text { T-stat } \\ 16.42^{* * *} & 0.249 & 15.44^{* * *} \\ 14.14^{* * *} & 0.317 & 13.89^{* * *}\end{array}$


Table 5: Regression of PEAD and liquidity costs (Spread, RtoV, and RtoTR) for zero-leverage firms

Table 5 represents the results of earnings response coefficient regressions to examine PEAD for earnings surprises of zero-leverage firms around the earnings announcement date, using the following pooled model.

PEAD $_{i, t}=\beta_{0}+\beta_{1} U E_{i, t}+\beta_{2}$ Illiquidity $_{i, t}+\beta_{3}$ Vol $_{i, t}+\beta_{4}$ Size $_{i, t}+\beta_{5}$ StdDev $_{i, t}+\beta_{6}$ Price $_{i, t}+\varepsilon_{\mathrm{t}}$

$P E A D_{i, t}$ represents either PEAD3 or PEAD60, for stock $i$ in time period $t$. Independent variables include the $U E$, which is the earnings surprise measured using earnings expectations from a seasonal random walk model. Illiquidity $_{i, t}$ is the illiquidity measure Spread, RtoV or RtoTR. Vol $_{i, t}$, is the daily trading volume of stock $i$ at time $t$, Size $_{i, t}$ captures the market capitalization of firm $i$ at time $t$. StdDev $v_{i, t}$ represents daily return volatility at time period t. Price $_{i, t}$, is stock $i$ 's daily closing price. Two tailed tests of significance are reported as follows, ${ }^{* * *}$ denotes significance at $1 \%,{ }^{* *}$ denotes significance at $5 \%$ and ${ }^{*}$ denotes significance at $10 \%$

\begin{tabular}{|c|c|c|c|c|}
\hline \multirow[t]{2}{*}{ Spread } & \multicolumn{2}{|c|}{ PEAD 3} & \multicolumn{2}{|c|}{ PEAD 60} \\
\hline & Coef. & T-stat & Coef. & T-stat \\
\hline $\mathrm{C}$ & 2.455 & $7.24^{* * *}$ & 3.698 & $6.68^{* * *}$ \\
\hline UE & 0.004 & 1.29 & 2.128 & $3.45^{* * *}$ \\
\hline UE*Spread & -0.056 & $-1.98^{*}$ & -2.130 & $-3.31^{* * *}$ \\
\hline UE*Vol. & -1.234 & $-4.35^{* * *}$ & -0.717 & $-2.33^{* *}$ \\
\hline UE*Size & -0.010 & -1.33 & -0.003 & -1.05 \\
\hline UE*StdDev & -0.063 & $-1.98^{*}$ & -0.145 & $-2.84^{* *}$ \\
\hline UE*Price & 0.046 & 1.23 & 0.015 & 0.97 \\
\hline \multirow[t]{2}{*}{ RtoV } & \multicolumn{2}{|c|}{ PEAD 3} & \multicolumn{2}{|c|}{ PEAD 60} \\
\hline & Coef. & T-stat & Coef. & T-stat \\
\hline $\mathrm{C}$ & 1.088 & $6.35^{* * *}$ & 1.900 & $8.88^{* * *}$ \\
\hline UE & 0.006 & $2.07^{*}$ & 1.933 & $3.13^{* *}$ \\
\hline UE*RtoV & 0.011 & 1.24 & -1.969 & $-2.58^{* *}$ \\
\hline UE*Vol. & -1.105 & $-1.73^{*}$ & -0.860 & -1.25 \\
\hline UE*Size & -0.009 & -0.98 & -0.004 & -0.24 \\
\hline UE*StdDev & -0.054 & $-1.67^{*}$ & -0.201 & $-3.05^{* *}$ \\
\hline UE*Price & 0.035 & 1.33 & 0.026 & 0.98 \\
\hline \multirow[t]{2}{*}{ RtoTR } & \multicolumn{2}{|c|}{ PEAD 3} & \multicolumn{2}{|c|}{ PEAD 60} \\
\hline & Coef. & T-stat & Coef. & T-stat \\
\hline $\mathrm{C}$ & 0.946 & $4.13^{* * *}$ & 1.985 & $5.33^{* * *}$ \\
\hline UE & 0.003 & $1.84^{*}$ & 2.125 & $3.99^{* * *}$ \\
\hline UE*RtoTR & 0.009 & 1.11 & -2.018 & $-5.10^{* * *}$ \\
\hline UE*Vol. & -1.458 & $-4.23^{* * *}$ & -0.632 & $-2.85^{* *}$ \\
\hline UE*Size & -0.013 & -1.08 & -0.001 & -0.76 \\
\hline UE*StdDev & -0.073 & $-2.16^{*}$ & -0.186 & $-2.99^{* *}$ \\
\hline UE*Price & 0.044 & $1.52^{*}$ & 0.019 & 1.33 \\
\hline
\end{tabular}

Panel B: Zero-leverage firms after initial loan announcement

\begin{tabular}{|c|c|c|c|c|}
\hline \multirow[t]{2}{*}{ Spread } & \multicolumn{2}{|c|}{ PEAD 3} & \multicolumn{2}{|c|}{ PEAD 60} \\
\hline & Coef. & T-stat & Coef. & T-stat \\
\hline $\mathrm{C}$ & 1.988 & $4.67^{* * *}$ & 3.987 & $9.25^{* * *}$ \\
\hline UE & 0.401 & 1.33 & 2.045 & $3.58^{* * *}$ \\
\hline UE*Spread & 0.231 & 1.24 & -1.860 & $-3.07^{* *}$ \\
\hline UE*Vol. & -1.633 & $-5.13^{* * *}$ & -0.685 & $-2.99^{* *}$ \\
\hline UE*Size & -0.191 & $-1.98^{*}$ & -0.143 & $-1.70^{*}$ \\
\hline UE*StdDev & -0.080 & $-1.69^{*}$ & -0.094 & $-2.58^{* *}$ \\
\hline UE*Price & 0.024 & $1.51^{*}$ & 0.014 & 1.43 \\
\hline \multirow[t]{2}{*}{ RtoV } & \multicolumn{2}{|c|}{ PEAD 3} & \multicolumn{2}{|c|}{ PEAD 60} \\
\hline & Coef. & T-stat & Coef. & T-stat \\
\hline $\mathrm{C}$ & 2.813 & $5.64^{* * *}$ & 3.025 & $6.69^{* * *}$ \\
\hline UE & 0.502 & 1.26 & 2.148 & $3.03^{* *}$ \\
\hline UE*RtoV & 0.131 & 1.00 & -1.843 & $-2.88^{* *}$ \\
\hline UE*Vol. & -1.135 & $-2.99^{* *}$ & -0.929 & $-2.02^{*}$ \\
\hline UE*Size & -0.129 & $-1.93^{*}$ & -0.126 & $-1.89^{*}$ \\
\hline UE*StdDev & -0.014 & -1.33 & -0.087 & $-2.31^{* *}$ \\
\hline UE*Price & 0.025 & $1.76^{*}$ & 0.013 & 1.08 \\
\hline \multirow[t]{2}{*}{ RtoTR } & \multicolumn{2}{|c|}{ PEAD 3} & \multicolumn{2}{|c|}{ PEAD 60} \\
\hline & Coef. & T-stat & Coef. & T-stat \\
\hline $\mathrm{C}$ & 2.094 & $4.38^{* * *}$ & 2.855 & $5.13^{* * *}$ \\
\hline UE & 0.226 & 1.37 & 1.994 & $3.41^{* * *}$ \\
\hline UE*RtoTR & -0.015 & $-1.98^{*}$ & -1.131 & $-3.02^{* *}$ \\
\hline UE*Vol. & -1.740 & $-3.56^{* * *}$ & -0.904 & $-2.11^{*}$ \\
\hline UE*Size & -0.200 & $-2.67^{* *}$ & -0.124 & $-1.88^{*}$ \\
\hline UE*StdDev & -0.015 & $-1.98^{*}$ & -0.047 & $-2.53^{* *}$ \\
\hline UE*Price & 0.019 & 1.03 & 0.013 & 0.68 \\
\hline
\end{tabular}




\section{Table 6: Regression of PEAD and liquidity costs (Spread decomposition) for zero-leverage firms}

Table 6 represents the results of earning response coefficient regressions to examine the PEAD to earnings surprise of zeroleverage firms around the earnings announcement day.

PEAD $D_{i, t}=\beta_{0}+\beta_{1} U E_{i, t}+\beta_{2}$ Illiquidity $_{i, t}+\beta_{3}$ Vol $_{i, t}+\beta_{4}$ Size $_{i, t}+\beta_{5}$ StdDev $_{i, t}+\beta_{6}$ Price $_{i, t}+\varepsilon_{\mathrm{t}}$

Regression variables are defined as: PEAD $D_{i, t}$ represents either PEAD3 or PEAD60, for stock $i$ at time period $t$. Independent variables include the $U E$, is the earnings surprises measured using earnings expectation from a seasonal random walk model. Illiquidity $_{i, t}$ is the three spread components of zero-leverage firms, adverse selection costs $(\alpha)$, inventory holding costs $(\beta)$,or order processing costs $(1-(\alpha+\beta))$. Vol $_{i, t}$ is the daily trading volume of the stock $i$ at time $t$, Size $e_{i, t}$ captures the market capitalization of the firm $i$ at time $t$. StdDev $v_{i, t}$ represents daily return volatility at time period t. Price $e_{i, t}$, is the stock $i$ 's daily closing price. Two tailed tests of significance are reported as follows, ${ }^{* * *}$ significance at $1 \%,{ }^{* *}$ significance at $5 \%$ and ${ }^{*}$ significance at $10 \%$

\begin{tabular}{|c|c|c|c|c|}
\hline \multicolumn{5}{|c|}{ Panel A: Zero-leverage firms before initial loan announcement } \\
\hline \multirow[t]{2}{*}{ Adverse Selection } & \multicolumn{2}{|c|}{ PEAD 3} & \multicolumn{2}{|c|}{ PEAD 60} \\
\hline & Coef. & T-stat & Coef. & T-stat \\
\hline $\mathrm{C}$ & 2.044 & $4.38^{* * *}$ & 4.025 & $5.99^{* * *}$ \\
\hline UE & 0.015 & $1.94^{*}$ & 3.449 & $3.93^{* * *}$ \\
\hline $\mathrm{UE}^{*} \alpha$ & -0.032 & $-2.04^{*}$ & -3.457 & $-3.85^{* * *}$ \\
\hline UE*Vol. & -1.613 & $-4.28^{* * *}$ & -0.804 & $-2.57^{* *}$ \\
\hline UE*Size & -0.013 & -1.26 & -0.007 & -1.04 \\
\hline UE*StdDev & -0.017 & $-2.08^{*}$ & -0.103 & $-3.48^{* * *}$ \\
\hline UE*Price & 0.013 & 1.37 & 0.007 & 0.73 \\
\hline \multirow[t]{2}{*}{ Inventory Holding } & \multicolumn{2}{|c|}{ PEAD 3} & \multicolumn{2}{|c|}{ PEAD 60} \\
\hline & Coef. & T-stat & Coef. & T-stat \\
\hline $\mathrm{C}$ & 2.810 & $5.22^{* * *}$ & 3.074 & $7.33^{* * *}$ \\
\hline UE & 0.023 & 0.95 & 2.358 & $3.21^{* *}$ \\
\hline $\mathrm{UE} * \beta$ & -0.014 & -1.04 & -0.215 & -1.26 \\
\hline UE*Vol. & -1.035 & $-2.28^{*}$ & -0.637 & $-2.00^{*}$ \\
\hline UE*Size & -0.010 & $-1.77^{*}$ & -0.005 & -1.33 \\
\hline UE*StdDev & -0.009 & -1.03 & -0.094 & $-1.87^{*}$ \\
\hline UE*Price & 0.020 & $1.99^{*}$ & 0.009 & 0.88 \\
\hline \multirow[t]{2}{*}{ Order Processing } & \multicolumn{2}{|c|}{ PEAD 3} & \multicolumn{2}{|c|}{ PEAD 60} \\
\hline & Coef. & T-stat & Coef. & T-stat \\
\hline $\mathrm{C}$ & 3.005 & $7.83^{* * *}$ & 2.036 & $6.45^{* * *}$ \\
\hline UE & 0.011 & 1.27 & 2.014 & $2.69^{* *}$ \\
\hline $\mathrm{UE}^{*}(1-\alpha-\beta)$ & -0.000 & -0.76 & -0.312 & -1.28 \\
\hline UE*Vol. & -1.238 & $-3.33^{* * *}$ & -0.737 & $-2.39^{* *}$ \\
\hline UE*Size & -0.012 & -0.91 & -0.009 & -0.86 \\
\hline UE*StdDev & -0.034 & $-1.98^{*}$ & -0.125 & $-2.44^{* *}$ \\
\hline UE*Price & 0.017 & 1.43 & 0.003 & 0.69 \\
\hline
\end{tabular}

Panel B: Zero-leverage firms after initial loan announcement

\begin{tabular}{|c|c|c|c|c|}
\hline \multirow[t]{2}{*}{ Adverse selection } & \multicolumn{2}{|c|}{ PEAD 3} & \multicolumn{2}{|c|}{ PEAD 60} \\
\hline & Coef. & T-stat & Coef. & T-stat \\
\hline $\mathrm{C}$ & 2.866 & $4.79^{* * *}$ & 2.064 & $5.28^{* * *}$ \\
\hline UE & 0.214 & $1.98^{*}$ & 2.339 & $3.15^{* *}$ \\
\hline $\mathrm{UE}^{*} \alpha$ & -0.338 & $-2.01^{*}$ & -2.069 & $-3.18^{* *}$ \\
\hline UE*Vol. & -1.269 & $-3.96^{* * *}$ & -0.938 & $-1.99^{*}$ \\
\hline UE*Size & -0.236 & $-2.58^{* *}$ & -0.203 & $-2.36^{* *}$ \\
\hline UE*StdDev & -0.013 & $-1.77^{*}$ & -0.056 & $-2.04^{*}$ \\
\hline UE*Price & 0.016 & 1.39 & 0.008 & 1.03 \\
\hline \multirow[t]{2}{*}{ Inventory cost } & \multicolumn{2}{|c|}{ PEAD 3} & \multicolumn{2}{|c|}{ PEAD 60} \\
\hline & Coef. & T-stat & Coef. & T-stat \\
\hline $\mathrm{C}$ & 3.001 & $4.74^{* * *}$ & 3.009 & $7.28^{* * *}$ \\
\hline UE & 0.302 & $1.66^{*}$ & 1.950 & $3.33^{* * *}$ \\
\hline $\mathrm{UE} * \beta$ & -0.109 & -0.94 & -0.936 & -1.25 \\
\hline UE*Vol. & -1.003 & $-3.18^{* *}$ & -0.543 & $-1.91^{*}$ \\
\hline UE*Size & -0.191 & $-2.25^{* *}$ & -0.134 & $-2.18^{*}$ \\
\hline UE*StdDev & -0.013 & $-1.77^{*}$ & -0.057 & $-2.04^{*}$ \\
\hline UE*Price & 0.008 & $1.48^{*}$ & 0.007 & 0.96 \\
\hline \multirow{2}{*}{ Order processing } & \multicolumn{2}{|c|}{ PEAD 3} & \multicolumn{2}{|c|}{ PEAD 60} \\
\hline & Coef. & T-stat & Coef. & T-stat \\
\hline $\mathrm{C}$ & 3.610 & $4.19^{* * *}$ & 2.881 & $6.51^{* * *}$ \\
\hline UE & 0.231 & $2.07^{*}$ & 2.008 & $3.91^{* * *}$ \\
\hline $\mathrm{UE}^{*}(1-\alpha-\beta)$ & -0.024 & -1.30 & -0.168 & -1.13 \\
\hline UE*Vol. & -1.654 & $-3.03^{* *}$ & -0.726 & $-2.40^{* *}$ \\
\hline UE*Size & -0.203 & $-1.91^{*}$ & -0.114 & $-1.64^{*}$ \\
\hline UE*StdDev & -0.009 & -1.03 & -0.029 & $-1.67^{*}$ \\
\hline UE*Price & 0.014 & $1.49^{*}$ & 0.003 & 0.93 \\
\hline
\end{tabular}


Table 7: Regression of PEAD and liquidity costs for all levered firms

Table 7 represents the results of earnings response coefficient regressions to examine PEAD for earnings surprises for all levered FTSE350 firms around the earnings announcement date, using the following pooled model.

PEAD $D_{i, t}=\beta_{0}+\beta_{1} U E_{i, t}+\beta_{2}$ Illiquidity $_{i, t}+\beta_{3}$ Vol $_{i, t}+\beta_{4}$ Size $_{i, t}+\beta_{5}$ StdDev $_{i, t}+\beta_{6}$ Price $_{i, t}+\varepsilon_{\mathrm{t} .}$

$P E A D_{i, t}$ represents either PEAD3 or PEAD60, for stock $i$ in time period $t$. Independent variables include the $U E$, which is the earnings surprise measured using earnings expectations from a seasonal random walk model. Illiquidity $i, t$ is the illiquidity measure Spread, RtoV or RtoTR. Vol ${ }_{i, t}$, is the daily trading volume of stock $i$ at time $t$, Size $_{i, t}$ captures the market capitalization of firm $i$ at time $t$. StdDev $v_{i, t}$ represents daily return volatility at time period t. Price $_{i, t}$, is stock $i$ 's daily closing price. Two tailed tests of significance are reported as follows, ${ }^{* * *}$ denotes significance at $1 \%,{ }^{* *}$ denotes significance at $5 \%$ and ${ }^{*}$ denotes significance at $10 \%$

\begin{tabular}{|c|c|c|c|c|}
\hline \multirow{2}{*}{\multicolumn{5}{|c|}{ Panel A: Spread, RtoV, RtoTR }} \\
\hline \multirow[t]{2}{*}{ Spread } & & PEAD 3 & \multicolumn{2}{|c|}{ PEAD 60} \\
\hline & Coef. & T-stat & Coef. & T-stat \\
\hline $\mathrm{C}$ & 2.341 & $5.26^{* * *}$ & 4.448 & $7.25^{* * *}$ \\
\hline UE & 0.025 & 1.46 & 1.306 & $3.49^{* * *}$ \\
\hline UE*Spread & -0.014 & -1.33 & -1.646 & $-3.77^{* * *}$ \\
\hline UE*Vol. & -1.313 & $-3.38^{* * *}$ & -0.721 & $-2.83^{* *}$ \\
\hline UE*Size & -0.248 & $-2.14^{*}$ & -0.203 & $-1.76^{*}$ \\
\hline UE*StdDev & -0.031 & $-1.66^{*}$ & -0.065 & -1.35 \\
\hline UE*Price & 0.021 & 1.42 & 0.020 & 1.13 \\
\hline \multirow[t]{2}{*}{ RtoV } & \multicolumn{2}{|c|}{ PEAD 3} & \multicolumn{2}{|c|}{ PEAD 60} \\
\hline & Coef. & T-stat & Coef. & T-stat \\
\hline $\mathrm{C}$ & 2.936 & $5.20^{* * *}$ & 3.458 & $7.09^{* * *}$ \\
\hline UE & 0.016 & 1.01 & 1.457 & $4.01^{* * *}$ \\
\hline UE*RtoV & -0.024 & -1.26 & -1.104 & $-3.64^{* * *}$ \\
\hline UE*Vol. & -1.174 & $-3.45^{* * *}$ & -0.832 & $-2.99^{* *}$ \\
\hline UE*Size & -0.136 & $-1.74^{*}$ & -0.124 & $-1.63^{*}$ \\
\hline UE*StdDev & -0.024 & -1.25 & -0.043 & -1.07 \\
\hline UE*Price & 0.019 & 1.05 & 0.012 & 0.72 \\
\hline \multirow[t]{2}{*}{ RtoTR } & \multicolumn{2}{|c|}{ PEAD 3} & \multicolumn{2}{|c|}{ PEAD 60} \\
\hline & Coef. & T-stat & Coef. & T-stat \\
\hline $\mathrm{C}$ & 1.590 & $3.24^{* *}$ & 2.308 & $4.99^{* * *}$ \\
\hline UE & 0.020 & 1.32 & 1.263 & $3.77^{* * *}$ \\
\hline UE*RtoTR & -0.033 & -1.41 & -1.438 & $-3.92^{* * *}$ \\
\hline UE*Vol. & -1.023 & $-3.08^{* *}$ & -0.719 & $-2.54^{* *}$ \\
\hline UE*Size & -0.200 & $-1.90^{*}$ & -0.132 & $-1.81^{*}$ \\
\hline UE*StdDev & -0.017 & -1.23 & -0.037 & -1.22 \\
\hline UE*Price & 0.020 & 1.33 & 0.013 & 1.14 \\
\hline
\end{tabular}

Panel B: Spread Decomposition

\section{Adverse selection}

C

UE

$\mathrm{UE} * \alpha$

UE*Vol.

UE*Size

UE*StdDev

UE*Price

Inventory holding

C

UE

$\mathrm{UE} * \beta$

UE*Vol.

UE*Size

UE*StdDev

UE*Price

Order Processing

C

UE

$U E^{*}(1-\alpha-\beta)$

$\mathrm{UE*}$ Vol.

UE*Size

UE*StdDev

UE*Price
PEAD 3

T-stat

$7.18^{* * * *}$
$2.19^{* *}$

$-1.87^{*}$

$-3.31^{* * *}$

$-2.00 *$

$-1.24$

$1.96^{*}$

PEAD 3

0.014

Coef.

3.097

0.106

$-0.089$

$-1.004$

$-0.271$

$-0.007$

0.004

Coef.

4.133

0.201

$-0.017$

$-1.007$

$-0.204$

$-0.011$

0.019
T-stat

$7.45^{* * *}$

$1.53^{*}$

$-1.24$

$-3.23^{* *}$

$-1.97^{*}$

$-0.88$

0.79

PEAD 3

T-stat

$8.64^{* * *}$

2.02

$-0.93$

$-3.44^{* * *}$

$-2.13$

$-0.45$

1.33
PEAD 60

T-stat

$7.44^{* * * *}$

$3.85^{* * *}$

$-3.91^{* * *}$

$-2.38^{* *}$

$-1.69^{*}$

$-1.54^{*}$

$1.48^{*}$

PEAD 60

T-stat

$9.06^{* * *}$

$3.12^{* *}$

$-2.33^{* *}$

$-2.82^{* *}$

$-1.61^{*}$

$-1.28$

0.46

PEAD 60

T-stat

$8.00^{* * * * *}$

$3.96^{* * *}$

$-1.53^{*}$

$-2.91^{* *}$

$-1.76$

$-1.20$

1.04 
Table 8: Robustness test: Regression of PEAD and liquidity costs using different event windows Table 8 represents the results of earnings response coefficient regressions to examine the PEAD to earnings surprise of zeroleverage firms around the different short-and long-run event window earnings announcement day.

PEAD $D_{i, t}=\beta_{0}+\beta_{1} U E_{i, t}+\beta_{2}$ Illiquidity $_{i, t}+\beta_{3}$ Vol $_{i, t}+\beta_{4}$ Size $_{i, t}+\beta_{5}$ StdDev $_{i, t}+\beta_{6}$ Price $_{i, t}+\varepsilon_{\mathrm{t}}$

Regression variables are defined as: PEAD $D_{i, t}$ represents either PEAD5,PEAD10, PEAD20 or PEAD40, for stock $i$ at time period $t$. Independent variables include the $U E$, is the earnings surprises measured using earnings expectation from a seasonal random walk model. Illiquidity ${ }_{i, t}$ is the illiquidity measure Spread, RtoV, or RtoTR. Vol ${ }_{i, t}$ is the daily trading volume of stock $i$ at time $t$, Size $_{i, t}$ captures the market capitalization of firm $i$ at time $t$. StdDev $v_{i, t}$ represents daily return volatility at time period t. Price $e_{i, t}$, is the stock $i$ 's daily closing price. Two tailed tests of significance are reported as follows, ${ }^{* * *}$ significance at $1 \%,{ }^{* *}$ significance at $5 \%$ and ${ }^{*}$ significance at $10 \%$

Panel A: Spread, RtoV and RtoTR

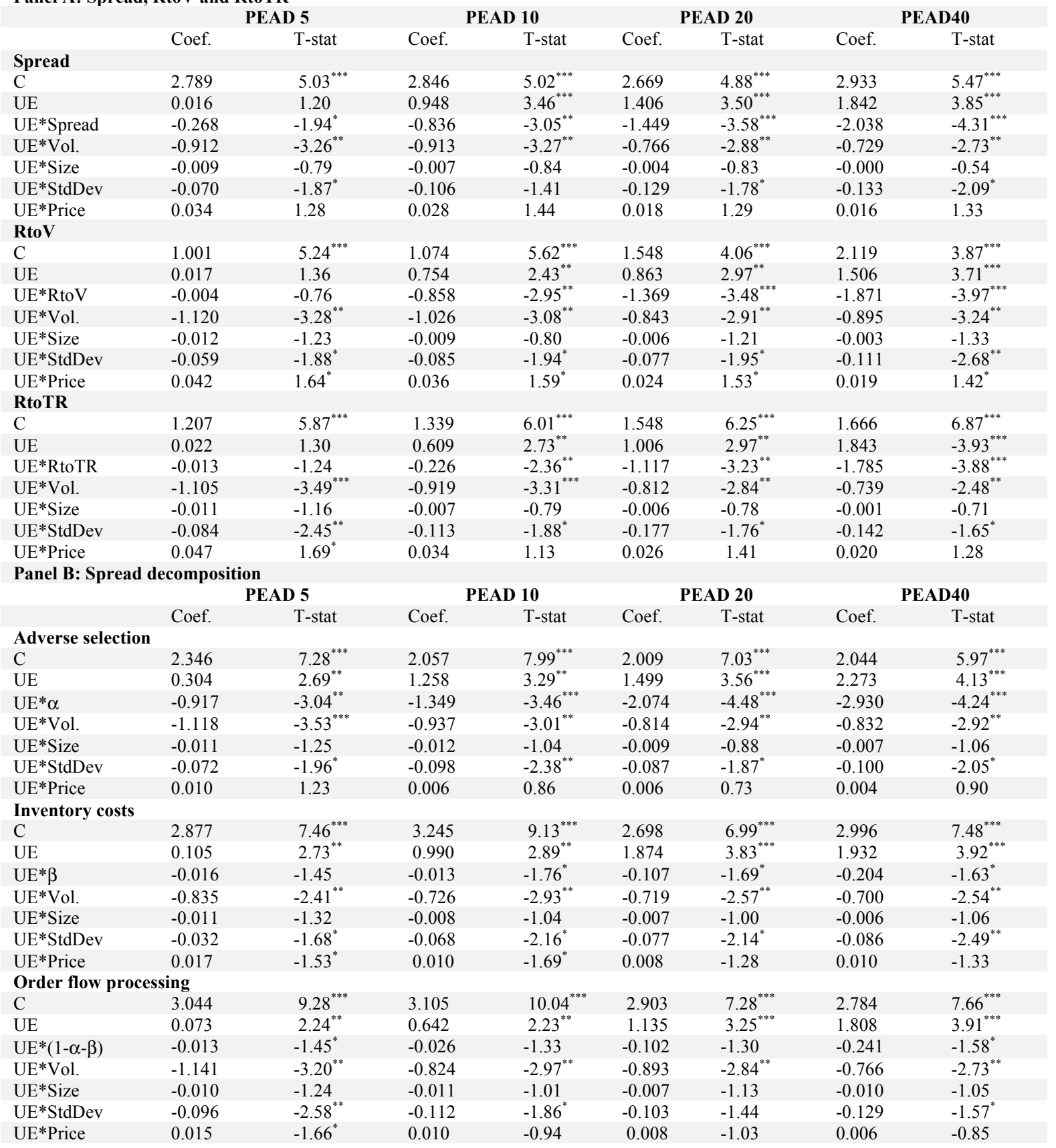


Table 9: Robustness test: Regression of PEAD and liquidity costs for different zero-leverage firm definitions

Table 9 represents the results of earnings response coefficient regressions to examine the PEAD to earnings surprise of zeroleverage firms around the earnings announcement day. Zero-leverage is defined as a firm with zero debt in one given year (Strebulaev and Yang (2013)). Alternatively, zero leverage is defined as a firm that does not have any debt for three consecutive years (Devos et al (2010)).

PEAD $D_{i, t}=\beta_{0}+\beta_{1} U E_{i, t}+\beta_{2}$ Illiquidity $_{i, t}+\beta_{3}$ Vol $_{i, t}+\beta_{4}$ Size $_{i, t}+\beta_{5}$ StdDev $_{i, t}+\beta_{6}$ Price $_{i, t}+\varepsilon_{\mathrm{t}}$

Regression variables are defined as: $P E A D_{i, t}$ represents either PEAD3, or PEAD60, for stock $i$ at time period $t$. Independent variables include the $U E$, is the earnings surprises measured using earnings expectation from a seasonal random walk model. Illiquidity $_{i, t}$ is the illiquidity measure Spread, RtoV, or RtoTR. Vol ${ }_{i, t}$ is the daily trading volume of stock $i$ at time $t$, Size $e_{i, t}$ captures the market capitalization of firm $i$ at time $t$. StdDev $v_{i, t}$ represents daily return volatility at time period t. Price $_{i, t}$, is the stock $i$ 's daily closing price. Two tailed tests of significance are reported as follows, ${ }^{* * *}$ significance at $1 \%,{ }^{* *}$ significance at $5 \%$ and ${ }^{*}$ significance at $10 \%$

Panel A: Spread, RtoV and RtoTR

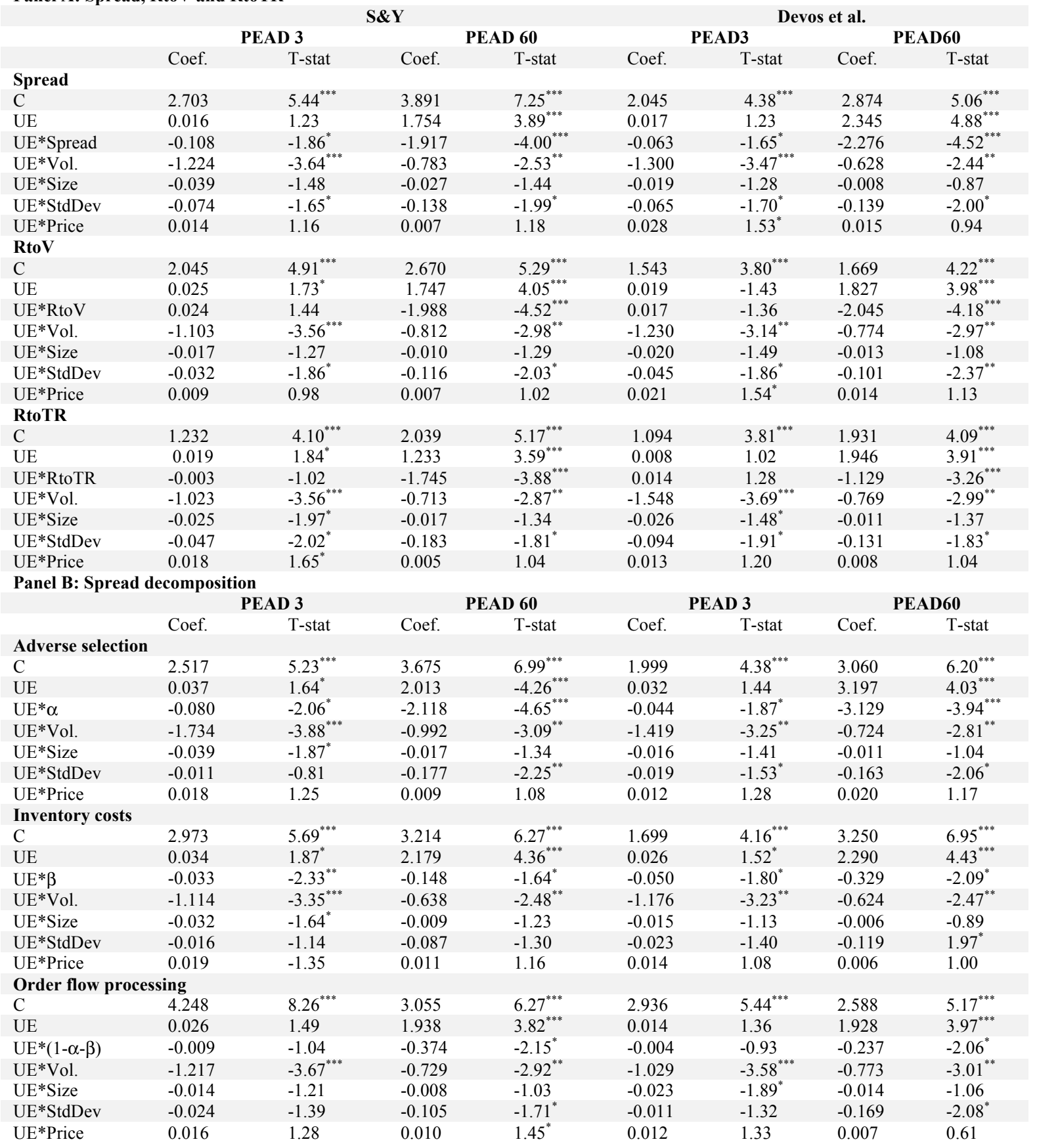

